\title{
La onomástica femenina de la dinastía meriní de Fez (siglos XIII-XV). Identificación y estudio*
}

\author{
Feminine Onomastic Traditions of the Merinid Dynasty \\ of Fes $\left(13^{\text {th }}-15^{\text {th }}\right.$ Centuries $)$. Identification and Study
}

\author{
Bárbara Boloix-Gallardo \\ Universidad de Granada \\ ORCID iD: https://orcid.org/0000-0003-3907-662X
}

\begin{abstract}
Resumen
El estudio de la onomástica femenina de los Banū Marīn de Fez ha adolecido, por lo general, de un análisis profundo y monográfico, a pesar de la gran utilidad de dichos nombres para definir mejor distintos rasgos de la idiosincrasia de esta estirpe. El objetivo principal del presente trabajo es cubrir precisamente dicha laguna científica, ofreciendo un análisis tanto filológico como socio-cultural del amplio catálogo de nombres femeninos presentes en el árbol genealógico meriní, desde el rigor científico. Como se intentará demostrar, tales denominaciones constituyen valiosos recursos para reconstruir la diversidad identitaria (étnica, geográfica, prosopográfica, cultural, etc.) no solo de este conjunto de mujeres, sino también de los soberanos con los que se relacionaron en distintas calidades familiares. Igualmente, tales nomenclaturas permiten identificar c on una mayor precisión las estrategias de legitimación político-religiosa que esta estirpe diseñó tanto en el plano socio-cultural árabe como en el religioso islámico.
\end{abstract}

Palabras clave: Mujeres; Reino meriní de Fez; onomástica; identidad; legitimación.

\begin{abstract}
The study of female onomastics of the Banū Marīn of Fez lacks a deep and monographic analysis, despite of being very useful to better define different features of the idiosyncrasy of this lineage. The main objective of this paper is precisely to cover this scientific gap, offering a philological and socio-cultural analysis of the wide catalog of female names present in the Merinid genealogical tree, from the scientific rigor. As we will try to demonstrate, such denominations constitute valuable resources to reconstruct the diverse identities (ethnic, geographical, prosopographic, cultural, etc.) of both these women and the sovereigns to whom they were related. Likewise, these names make it possible to identify with greater precision the strategies of political and religious legitimization that this dynasty designed in both the Arab socio-cultural scope and the Islamic religious sphere.
\end{abstract}

Key words: Women; Merinid Kingdom of Fez; Onomastics; Identity; Legitimation.

Cómo citar / Citation: Bolloix-Gallardo, Bárbara, "La onomástica femenina de la dinastía meriní de Fez (siglos XIII-XV). Identificación y estudio”, Al-Qanțara, 42, 2 (2021), e19. doi: https://doi.org/10.3989/alqantara.2021.016.

Recibido: 30/11/2020; Aceptado: 01/07/2021; Publicado: 07/02/2022

* Este trabajo es fruto del proyecto de Investigación I+D+i de Excelencia «La mujer nazarí y meriní en las sociedades islámicas del Mediterráneo medieval (siglos XIII-XV). Poder, identidad y dinámicas sociales» -NAZAMER- (Ref.: HAR201788117-P), financiado por el Ministerio de Economía y Competitividad, y la Agencia Estatal de Investigación, del que soy Investigadora Principal (http://nazamer.ugr.es/). Agradezco los comentarios y sugerencias de los/las revisores/as externos/as de Al-Qanțara, los cuales han contribuido a mejorar el contenido original de este artículo. 


\section{Introducción. La onomástica, un indicio de trascendencia plural}

El nombre propio (ism 'alam) ha sido siempre un elemento fundamental en la cultura islámica, constituyendo su imposición a la criatura recién nacida todo un acontecimiento en la vida familiar. La propia tradición islámica hacía especial incidencia en la importancia de que los progenitores eligiesen buenos nombres para sus hijos e hijas, aconsejando al respecto un hadiz que rezaba lo siguiente: «Vosotros see réis llamados en el Día del Juicio por vuestros nombres y los nombres de vuestros padres. Por lo tanto, elegid los mejores de vuestros nombres». El Corán ${ }^{1}$ reconoce, asimismo, la genealogía agnaticia de los nombres propios islámicos, dando el siguiente consejo: «Llamadles por su padre. Es más equitativo ante Dios».

A la hora de estudiar distintos aspectos relativos a la idiosincrasia de cualquier sociedad islámica, el análisis de la onomástica portada por sus sujetos tanto masculinos como femeninos resulta, por tanto, muy revelador. Así lo reconoce Helena de Felipe Rodríguez, para quien «el valor de los estudios onomásticos para realizar análisis de individuos y sociedades está totalmente confirmado» ${ }^{2}$. Y es que los nombres propios llevan implícitos una serie de datos de gran utilidad para reconstruir aspectos plurales de las identidades (étnica, cultural, lingüística, geográfica, confesional, etc.) de los sujetos estudiados, muchas veces extrapolables a los contextos sociales a los que pertenecen. Sin embargo, son igualmente bien conocidos los obstáculos que encuentra la investigación cuando dichos sujetos de estudio son de género femenino. Para empezar, adentrarse en la reconstrucción de un sector poblacional de esta naturaleza entraña por lo general, ya de por sí, «la dificultad añadida de que, en este caso, se dispone de un material mucho más limitado numéricamente», como señalaba Manuela Maa rín $^{3}$. Tales trabas parecen, aun así, suavizarse en cierta medida cuando se trata de mujeres de la realeza o de las clases altas (al-hāṣsa $)$ de las sociedades islámicas medievales - entre las que figuran tanto mujeres libres o nobles (harā'ir) como también esclavas de categoría superior vinculadas a grupos de poder-, pues

Aleya 5 de la azora 33, titulada "La Coalición" (al$A h z \bar{a} b)$; trad. Cortés, El Corán, p. 499.

2 Felipe Rodríguez, Identidad y onomástica, p. 37

3 Marín, Individuo y sociedad, pp. 178-179. son ellas las que sin duda tienen una mayor presencia en las fuentes ${ }^{4}$.

Tal es el caso que nos ocupa: el estudio de los nombres que portaron las mujeres de la familia meriní de Fez; un aspecto que hasta la fecha no ha sido abordado de una manera profunda y total a pesar de la gran utilidad que la onomástica puede tener para desvelar diversos rasgos de la idiosincrasia de esta estirpe. Entre ellos, figuran las estrategias de legitimación político-religiosa que aquella desarrolló, según explicaremos en breve, como dinastía bereber que fue. Recordemos que los Banū Marīn, pertenecientes a la tribu bereber Zanāta,controlaron la zona más occidental del Magreb (alMagrib al-aqsà) entre los siglos VII/XIII y IX/ $\mathrm{XV}$. Aunque previamente habían col aborado militarmente con los Almohades, los Meriníes - cuyo nombre hacía clara referencia al tipo de lana (merino) de gran calidad que producían por ser originariamente pastores nómadas y criadores de ovejas-, lograron suplantarlos en parte de sus territorios, aprovechando su decadencia. Así conquistaron grandes ciudades como Mekinés en 642/1244, Fez en 646/1248 (que convirtieron en su capital), Siğilmāsa en $653 / 1255 \mathrm{y}$, finalmente, la capital almohade, Marrakech, en 668/1269; unos dominios que, en el siglo VIII/XIV, quedarían ampliados con las conquistas de Tremecén en 737/1337 y del área de Túnez en 748/1347, con las que lograron controlar buena parte del Magreb ${ }^{5}$.

A pesar de haber compartido origen étnico bereber (aunque no tribal) con los Almohades, los Meriníes se diferenciaron de estos en el tratamiento historiográfico que dieron a las mujeres de su estirpe. Si bien aquellos se habían caracterizado por una consciente ocultación del sector femenino en sus crónicas - tal vez como reacción a la explícita exhibición, física e historiográfica, que los Almorávides habían hecho previamente de sus mujeres, que ni siquiera tenían que ir veladas en los espacios públicos-, los Meriníes, por el contrario, concedieron un especial protagonismo a la figura femenina como piedra angular de la familia en su producción escrita. Aunque esta estuvo enmarcada en la tradición arabo-islámica, comportó una actitud algo más abierta hacia el reflejo textual femenino a diferencia también de las sociedades árabes, mucho más reservadas, por lo

\footnotetext{
4 Marín, Mujeres, p. 49.

Shatzmiller,"Marīnids", en $E I^{2}$
} 
general, que las bereberes en el tratamiento de las mujeres en las crónicas por ser estas consideradas espacios de manifiesta visibilización ${ }^{6}$, como han observado distintos especialistas ${ }^{7}$. Tal vez pueda justificar este hecho la reflexión de Maya Shatzmiller ${ }^{8}$, para quien la historiografía meriní constituye un caso particular y en ella, como en otras tradiciones, advertimos la influencia mutua existente entre sociedad e historiografía. Así, aunque Amira Bennison ${ }^{9}$ afirmó que las mujeres del Magreb pre-moderno habían dejado una escasa huella en las fuentes conservadas, en realidad es posible reconstruir muchos aspectos suyos en la producción escrita generada por los Banū Marīn, entre ellos el de sus tradiciones onomásticas y sus identidades socio-culturales; rasgos que redundan en un mejor conocimiento de la historia de esta dinastía.

Descendiendo al detalle, el amplio catálogo de las denominaciones femeninas meriníes adquiere un valor exponencial al revelar los plurales rasgos, ya señalados, de su diverso «harén» (al-harim o al-huram $)^{10}$. Consta por las fuentes árabes que los emires de esta dinastía tomaron tanto esposas legales (azwāğ) como concubinas (ummāhāt al-awlād) para engendrar a sus hijos y perpetuar su linaje. Por lo general, las mujeres libres $(a h r \bar{a} r)$ de este reino solían tener un origen bereber o árabe, mientras que las esclavas ( 'abìd) eran bien de origen cristiano (en el caso de las cautivas procedentes de los reinos cristianos de la península Ibérica) bien sub-sahariano (en el de las de color) ${ }^{11}$. Cada uno de estos colectivos se caracterizó también por su heterogeneidad pues, lejos de ser internamente uniformes, presenta una variedad de matices que también debe ser analizada en función de la onomástica y de otros rasgos que revelan las crónicas.

Por otro lado, los nombres de dichas mujeres trascienden el plano puramente social para adentrarse en el político, al ofrecer a veces indicios claros tanto de las orientaciones

6 Sobre la sociedad bereber, véase Basset, y [Pellat], "Berbers", pp. 1173-1187; González, "Berbers", vol. I, p. 105.

7 Marcy, "Le vestiges"; Basset, y [Pellat], "Berbers", p.

1179; Garulo,"Woman in Medieval", p. 34; Jiménez Estacio, "Las mujeres bereberes".

8 L'historiographie mérinide, p. 1.

9 Bennison, "Morocco", p. 334.

10 Entendido como el conjunto de mujeres privado y privativo de un soberano que resultaba, en consecuencia, prohibido (harām) para otros hombres. Marín, Mujeres, p. 34; Boloix Gallardo, "Los harenes".

11 Bennison, "Morocco", p. 334. ideológicas de su linaje como de los recursos sobre los que este cimentó su legitimación político-religiosa. Sobre ello reflexionó Miguel Ángel Manzano al plantearse si podían «rase trearse, a partir de la onomástica de una dinastía, determinados problemas relacionados con la legitimidad del poder» o si «podría la onoe mástica contradecir los criterios de la legitimidad de esta dinastía» ${ }^{12}$. Aunque buena parte de las denominaciones femeninas de los Meriníes fueron de tradición bereber, su adscripción a esta etnia les obligó, por otro lado, a esforzarse profundamente por acreditar un remoto origen étnico árabe y religioso islámica. Considerando la estrecha identificación de ambos elementos, los Banū Marīn tuvieron que diseñar una vinculación propia con ellos para asentar su legitimidad, convirtiéndose a veces la onomástica, en este caso femenina, en un vehículo expresivo de la misma. Esta intención llevó a los Meriníes a adoptar también, junto a denominaciones en tamazig o lengua bereber, nombres árabes e islámicos para sus mujeres, llegando incluso a veces a una dualidad onomástica expresada en ambas lenguas ${ }^{13}$.

A lo largo de este estudio pretendemos, pues, realizar una identificación y un análisis filológico del amplio elenco de nombres que portaron las mujeres de la dinastía meriní a lo largo de su historia, cuya traducción socio-cultural aportaremos igualmente. Considerando la falta de estudios dedicados, de manera total, a este aspecto, nuestro objetivo es cubrir dicha laguna y, con ello, lograr un mejor conocimiento tanto de las mujeres de esta familia como de la propia dinastía, conscientes de la necesidad de aplicar la perspectiva de género al estudio de su trayectoria; pues, como afirmara la historiadora estadounidense Joan W. $\mathrm{Scott}^{14}$, «una metodología como ésta implica no solo una nueva historia de las mujeres, sino también una nueva historia», en este caso, del reino meriní de Fez. Para cumplir con este objetivo, partiremos del análisis filológico (árabe, fundamentalmente, pero también bereber) de aquellos nombres femeninos hallados en una selección de crónicas meriníes, las cuales constituirán el principal soporte textual sobre el que se apoyará el presente estudio.

\footnotetext{
12 Manzano Rodríguez, “Onomástica benimerín”, p. 120.

13 Manzano Rodríguez, "Onomástica benimerín”, pp. 122-124.

14 Scott, "El género: una categoría útil para el análisis histórico", p. 267.
} 


\section{La onomástica femenina: un útil recurso en la arabización genealógica de los Banū Marīn}

En su trabajo titulado "Onomástica benimerín: el problema de la legitimidad", Miguel Ángel Manzano comenzaba reflexionando sobre cómo la dinastía meriní «carecía, como otras [corporaciones nómadas], de un pasado reconocido, de un origen de hondas raíces históricas que le permitiera llevar a cabo su labor de conquista y expansión por el Magreb sin toparse (...) con planteamientos teóricos que le oponía la élite intelectual de la sociedad, o con un sentimiento popular insistentemente adverso ${ }^{15}$. A diferencia de sus predecesores, Almorávides y Almohades, los Meriníes no habían alcanzado el poder en el Magreb sobre la base de ideología religiosa revivificadora del Islam, ni tampoco podían, como aquellos últimos, proclamarse califas ni descendientes de jerifes ( $\breve{s u r a f a ̂ a}$ ), por lo que canalizaron su legitimación mediante la adopción de un supuesto origen árabe y una defensa a ultranza del Islam ortodoxo ${ }^{16}$. El intenso proceso de islamización que los Meriníes emprendieron entre finales del siglo XII y principios del XIII entrañó una serie de cambios identitarios sustanciales que afectaron, fundamentalmente, al replanteamiento de su genealogía con el fin de plasmar en ella el doble proceso de transición experimentado por este colectivo: de su propia ğãhiliyya a la islamización, por un lado, y de su etnia bereber a una identificación con un supuesto origen árabe ancestral, por otro ${ }^{17}$.

Para lograr la arabización del linaje, los Banū Marīn trazaron una nueva cadena genealógica o nasab en la que incluyeron a prestigiosos ascendientes masculinos de nombres árabes. Sin embargo, la veracidad de dicha filiación genealógica fue cimentada, por otra parte, sobre la construcción de una serie de historias legendarias con las que sus crónicas trataron de justificar esos supuestos orígenes, jugando en esta estrategia la lengua árabe un papel esencial ${ }^{18}$. Como reflejan dichas anécdo-

15 Manzano Rodríguez, “Onomástica benimerín”, p. 119.

16 Manzano Rodríguez, "Onomástica benimerín”, p. 119; El Hour, "Reflexiones", p. 55; Cory, "Honouring the Prophet's Family”, pp. 111 y 118.

17 Manzano Rodríguez, "Onomástica benimerín”, pp. 122-123 y nota 14

18 El Hour, "Reflexiones", p. 55; Véase especialmente Felipe, "Leyendas árabes", pp. 386-487 y Fierro, "Las genealogías", p. 87. Agradezco a mi compañera Helena de Felipe tas, ciertas mujeres ejercieron un protagonismo esencial en la acreditación de la «arabidad» ${ }^{19}$ de esta dinastía desde sus propias denominaciones onomásticas. Así, las principales fuentes dedicadas a registrar los orígenes de los Banū Marīn ya indican su supuesta procedencia materna árabe. En su Rawd al-qirțās ${ }^{20}$, Ibn Abī Zar' (m. 715/1315) remonta las raíces familiares de los Meriníes a Muḍar b. Nizār, figura originaria de una de las dos tribus árabes más importantes del norte de la península de Arabia. El propio autor ya refiere el origen matriz árabe de la familia meriní, pues revela que este Muḍar tuvo dos hijos varones - Ilyās e 'Aylān - con una mujer llamada precisamente al-Rabāb bint Ğanda ${ }^{21}$ b. 'Amr b. Ma'add b. 'Adnān, nombre que significa «la Nube blanf ca» o también «el Rabel» $»^{22}$. Tanto la cadena genealógica de esta como su propia denominación ya reflejan una intención explícita de adjudicar un origen árabe materno a este linaje indudablemente bereber.

La siguiente mujer de la que tenemos noticias es Muzna bint Asad b. Rabī'a b. Nizāra ${ }^{23}$, la

los útiles consejos que me ofreció en el debate del Congreso Internacional «Las mujeres nazaríes y meriníes en el Mediterráneo islámico medieval (siglos XIII-XV)» (Granada, 6-7 junio 2019) para enfocar el análisis de los ancestrales nombres árabes femeninos presentes en las leyendas de legitimación genealógica y cultural de los Meriníes dentro de este estudio.

19 Aunque la formulación del concepto de «arabidad» ( 'urūba) sea moderna, podemos hallarlo reflejado ya en algunos textos medievales bajo la voz 'urübiyyya. En el contexto de la Edad Media, podríamos definirlo como un concepto que hace referencia fundamentalmente a una identidad cultural, y al prestigio del estatus social que esta representaba, y no tanto a una realidad racial, según lo explica Viguera, "La sociedad musulmana en al-Andalus: su reflejo en los textos", p. 34, basándose en su empleo por parte de Ibn al-Hațịb en su obra Al-Ihâțta fì aḩbār Garnāța, vol. I, p. 136. Sin embargo, en un contexto tanto bereber como medieval como el que nos ocupa, dicha pretensión de «arabidad» venía acompañada de una reivindicación genealógica árabe, sobre todo en el caso de las dinastías. Este concepto debe ser, pues, diferenciado del de arabización ( $t a$ ' $r i ̄ b)$, fenómeno que, como es bien sabido, consiste en la adopción de distintas manifestaciones de la cultura árabe, entre ellas la lengua, por parte de poblaciones o individuos ajenos a ella, sin que ello afecte a sus identidades étnicas ni religiosas.

20 Ibn Abī Zar` al-Fāsī, Al-Anīs al-muțib, p. 365; AlDahīra, p. 15.

${ }_{21}$ En la edición de Al-Dahīra (p. 15), se ofrece otra versión distinta de la genealogía de esta mujer, mencionada como Al-Rabāb bint Yīda.

22 Según Corriente, Diccionario árabe-español, p. 276.

23 Ibn Abī Zar' al-Fāsī, al-Anīs al-mutrib, p. 365. Cabe corregir la grafía del nombre ofrecida en la edición de esta obra, Mudna, por la de Muzna, dada la existencia de mujeres que respondían a este último nombre, y no al primero de ellos, 
cual se desposó con Qays, el hijo del mencionado 'Aylān b. Muḍar, ancestro del que decían descender los Meriníes. Tanto el propio significado del nombre de esta fémina ('Lluvia') como la tradición existente en su uso revelan que, muy probablemente, era una concubi$n^{24}$. El referido Qays b. 'Aylān tomaría como segunda esposa a una mujer bereber llamada Yarīg - transcrito en lengua árabe, a veces, como Barīg - bint Mağdalī b. Mağdūl b. Ammār/'Amr b. Muḍar/Mașfar al-Barbariyya al-Mağdūliyya ${ }^{25}$. Su cadena genealógica deja constancia de su origen amazigh o bereber ${ }^{26}$, algo acreditado también por su propio nombre, del que existen varias interpretaciones. Por un lado, se piensa que podría tratarse de un nombre originario de la era tardorromana, vándala o bizantina en su forma local indígena, no declinada, en la cual desapareció la -g o la -c final (col dileguo ${ }^{27}$ pues, como señala Helena de Felipe ${ }^{28}$, «la onomástica constituye una

en la historia del Islam medieval, y ante el hecho de que así es mencionada en Al-Dahīra al-saniyya, p. 15.

24 Bajo esta denominación, que hace referencia a un fenómeno de la naturaleza tan apreciado por los árabes como es la lluvia, están registradas de hecho varias mujeres de distintas dinastías de la historia del Islam: la esposa del último califa omeya de Damasco, Marwān II (127-132/744-750); la mujer del emir Muhammad y madre del califa omeya de Córdoba 'Abd al-Raḥmān III (300-350/912-961), una mujer de origen cristiano (rümiyya), posiblemente vascón; una esclava ( ̌̌āriyya) del alcázar omeya de Córdoba que acabó siendo escritora ( $a d \bar{i} b a$ ) y secretaria del referido califa omeya, falleciendo en 358/968; y, por último, la madre del califa omeya Muhammad II al-Mahdī (399/1009; 400/1010).

25 Ibn Abī Zar' al-Fāsī, al-Anīs al-muțrib, p. 366; AlDahīra al-saniyya, pp. 15-16; Ibn al-Ahmar, Rawdat al-nisrīn, p. 17, donde se ofrece una cadena genealógica distinta (Yarīg bint Mağdal b. 'Umar b. Mașrām b. Barr b. Qay țb. Mașraym b. Hāzim b. Yāfit b. Nūḥ), y aparentemente menos fiable, de esta mujer, trad. Miguel Ángel Manzano, p. 8.

26 El término amazig / amahag (pl., imazigən / imuhag), cuyo significado es 'hombre libre', designa en lengua bereber (tamazig) a los bereberes en general, aunque ellos mismos, al carecer de todo sentido de comunidad, por lo general emplean sus nombres tribales cuando se refieren a sí mismos o han aceptado más o menos voluntariamente designaciones extranjeras. En cuanto al de «bereber», hunde sus raíces en la voz griega barbaroi y en la latina barbari, de las cuales pasó a la lengua árabe bajo las formas barbar / barbarī (pl., barābir / barābira); todos estos términos hacen referencia a la población autóctona del norte de África que habitaba el área comprendida desde la frontera egipcia (Sīwa) hasta las orillas del Océano Atlántico y la gran curva del Níger, y que se caracterizaban por hablar dialectos (o formas locales) de un único idioma, el bereber o tamazigh. Para esta definición, véase Pellat, Basset, y Galand,"Berbers".

27 Jud y Steiger (eds.), Vox romanica, vols. 13-14, p. 54.

28 Felipe Rodríguez, Identidad y onomástica, p. 40. muestra indiscutible de la impronta que los fenicios, romanos y árabes, principalmente, han dejado en su haber lingüístico y los nombres [bereberes] que señalamos a continuación son fiel reflejo de esta variedad». Sin embargo, sea gún Carles Múrcia esta denominación se podría analizar morfológicamente como una $3^{\text {a }}$ persona del singular masculino de un verbo en aoristo, algo muy corriente en antroponimia amazig, significando 'iQue él se libre (de cualquier peligro)!', ‘¿Que él se salve!' o '¡Que él salga indemne!' ${ }^{29}$. Por su parte, Hassan Akioud relaciona este nombre con la voz Yareg o $\mathrm{Ta}$ reg, este derivado del verbo areg ('ofrecer ayuda', 'obsequiar', 'regalar algo a alguien'). En ambos casos, Yarīg correspondería a un nombre masculino (cuya forma en femenino sería Tarig o Tareg), si bien está documentado entre los bereberes el uso de nombres de varón en mujeres.

El origen amazig de esta mujer sirvió claramente a los Meriníes para justificar historiográficamente la berberización cultural de sus supuestos orígenes árabes, justificándola en una ancestral proximidad con la etnia bereber. El relato transmitido al respecto por $\mathrm{Ibn} A b \overline{1}$ $Z^{\prime}{ }^{\prime 30}$ narra cómo, en tiempos antiguos, las tribus bereberes habitaban por aquel entonces en Siria $(a l-\breve{S} \bar{a} m)$, donde eran vecinos de los árabes tanto de dicha zona como de Palestina y Egipto, estando en contacto con sus viviendas, zocos y pastos: «Con ellos [los árabes] compartían el agua, los prados y los caminos, hasta el punto de que incluso establecían vínculos matrimoniales entre sí». Una de estas uniones inter-étnicas fue la de Qays b. 'Aylān con Yarīg, con la que, según el mismo cronista, tuvo dos hijos: un hijo llamado Barr y una hija llamada Tumāḍir ('Brillantez') ${ }^{31}$, ambos nombres árabes. Este Barr acabaría desposándose con una de las mujeres más hermosas de su tiempo, como reflejaba su propia onomástica: al-Bahā' ('la Hermosura'). Dada su galanura y belleza, esta mujer - que era descendiente de Muḍar y al-Rabāb a través de su nieto Dahmān b. 'Aylān - tenía múltiples pretendientes, entre ellos sus cuatro primos paternos por parte de su tío Qays (llamados, respectivamente,

29 Según este investigador, este verbo es poco frecuente en amazig septentrional, aunque subsiste en shawi, pero en tuareg es de uso común.

30 Ibn Abī Zar', Al-Anīs al-mutrib, p. 366; Al-Dahīra al-saniyya, p. 16.

31 Ibn Abī Zar', Al-Anīs al-mutrib, pp. 365-366; Al-Dahīra al-saniyya, p. 15. 
'Amr, Sa'd, Hafșa y el referido Barr). Ante los celos que provocó en los demás la unión de este último con al-Bahā', la madre de Barr - la ya mencionada bereber Yarīg — resolvió que el matrimonio marchara hacia la población en la que vivían sus propios hermanos bereberes para estar a salvo, donde fueron acogidos. Al-Bahā' le dio allí a Barr dos hijos: 'Alwān, quien murió siendo pequeño sin dejar descendencia, y Mādg̀īs, quien era apodado 'el mutilado' o 'el manco', y que sería el origen de la rama tribal bereber de al-Butr (literalmente, 'la amputación'), a la que la mayoría de los Zanāta remontaban sus genealogías. Barr fallecería en la tierra bereber de su familia materna, en la que había vivido «hablando la más pura lengua bereber y siguiendo sus mejores costumbres y tradiciones», como afirma Ibn Abī Zar', justificando así la familiaridad con la etnia bereber de esta rama familiar meriní ${ }^{32}$.

Centrándonos en la figura de Tumāḍir (hermana de Barr), su nombre constituyó otro exponente de la arabización genealógica de los Banū Marīn. Dicha denominación era árabe y de origen preislámico, siguiendo la tendencia de algunos bereberes de emplear nombres ğāhilies poco habituales ${ }^{33}$, propios de las primeras mujeres de la historia del Islam; entre ellas Tumāḍir bint al-Asbag, madre de Abū Salāma b. 'Abd al-Rahmmān b. 'Amr, la primera mujer kalbí en contraer nupcias con un qurayšs $\breve{l}^{34} ; \mathrm{y}$, de manera especial, la célebre poetisa al-Hansā' - llamada realmente Tumādir bint 'Amr bint al-Hart b. alŠarīd al-Sulamiyya (m. 24/645) ${ }^{35}$-, mujer que pasó a la literatura árabe clásica por haber compuesto sentidas elegías al óbito de sus hermanos. En la construcción legendaria de la ancestral Tumāḍir meriní podemos advertir una posible inspiración en esta figura literaria femenina pues esta mujer, tras llorar por el alejamiento de su hermano Barr de su casa paterna, sus parientes y su lengua árabe, también lamentó al igual que la célebre poetisa el posterior fallecimiento de este en los múltiples poemas que ella misma compuso, según indican las crónicas meriníes ${ }^{36}$.

32 Sobre la figura de Barr, véase la mención que de él hace Calasso, "Arabi e berberi”, p. 336.

33 Felipe Rodríguez, Identidad y onomástica, p. 46.

34 Ibn Sa 'd, Kitāb al-țabaqāt, vol. II, trad. 'A' iša Bewley, The Men of Madina, p. 103; Ibn Sa'd, Kitāb al-țabaqāt, vol. VIII, trad. 'Ā'iša Bewley, The Women of Madina, p. 207.

35 Gabrieli, Francesco, "Al-Khansā̄", p. 1027.

36 Ibn Abī Zar', Al-Anīs al-mutrib, p. 367; Al-Dahīra al-saniyya, p. 15-19; Ibn al-Ahmar, Rawdat al-nisrīn, p. 18.

\section{La onomástica de las mujeres reales meriníes ${ }^{37}$}

\subsection{Los nombres bereberes ${ }^{38}$}

A pesar de sus pretensiones de arabización étnica, los Meriníes no lograron ocultar completamente su naturaleza bereber, algo que se muestra de manera bastante evidente en la onomástica amazig de algunas mujeres de esta familia. Como comprobaremos, al menos trece féminas (entre ellas madres, esposas e hijas de emires) portaron nombres propios de esta lengua, haciendo con ello gala de su origen étnico amazig. A pesar de los interesantes rasgos socio-culturales que revela, el análisis de este elenco onomástico resulta el más difícil de desentrañar de todos por distintas razones: en primer lugar, la diversidad de los dialectos bereberes dificulta a veces la identificación de algunos nombres femeninos cuyo uso fue poco común; por otro lado, en nuestro estudio partimos de la base de unos nombres bereberes transcritos en árabe en las crónicas, lo que dificulta la identificación de las raíces de las que algunas de estas denominaciones pudieron proceder en tamazig, al estar sus versiones en lengua árabe bastante alteradas con respecto a la que debería ser su forma original. Un fenómeno que ya identificó Helena de Felipe, al señalar que «el desconocimiento de la lengua y la onomáss tica bereber que podemos presuponer entre los autores de las fuentes [árabes] produce ciertas fluctuaciones en las grafías ${ }^{39}$, casos en los que lanzaremos hipótesis sobre su semántica.

Consta el empleo de nomenclaturas bereberes femeninas ya en tiempos del fundador de la

\footnotetext{
37 Para la identificación de algunas de las mujeres cuyos nombres son analizados en este epígrafe en el contexto familiar de los Banū Marīn, y un mejor seguimiento de su contenido, remitimos al árbol genealógico ofrecido por Miguel Ángel Manzano, a modo de anexo, al final de su traducción de la crónica Rawdat al-nisrīn de Ibn al-Ahmar.

38 Quisiera agradecer explícitamente la generosa ayuda que me han brindado Carles Múrcia (Universitat de Barcelona) y Hassan Akioud (Institut Royal de la Culture Amazighe -IRCAM-, Rabat, Marruecos) en la difícil tarea de desentrañar el significado de algunos nombres femeninos que expondré en este apartado, sobre todo, dado el hecho de que sus transcripciones en árabe desvirtuaron con frecuencia las versiones originales de dichas nomenclaturas, a veces difíciles de identificar. Igualmente, me han resultado de gran utilidad los citados trabajos de Miguel Ángel Manzano Rodríguez ("Onomástica benimerín...", traducción anotada de la Rawdat al-nisrīn...) y de Helena de Felipe Rodríguez (Identidad y onomástica ...) tanto para la traducción al español de algunas de estas denominaciones femeninas como en la identificación de rasgos propios de las tradiciones onomásticas bereberes.

39 Felipe Rodríguez, Identidad y onomástica, p. 41.
} 
dinastía meriní, 'Abd al-Ḥaqq al-Marīnī (592614/1195-1217), quien engendró una numerosa prole con distintas mujeres, algunas de ellas esposas legítimas y otras, seguramente concubinas $^{40}$. De entre las primeras, su tercera esposa fue una mujer bereber llamada Tā'zūnt bint Abī Bakr b. Hafṣ, perteneciente a los Banū Tanaluft y, según Ibn Abī Zar'41, a la dinastía 'Abd al-Wādí de Tremecén; una mujer con la que tuvo a su hijo, el emir Abū Yahyà Abū Bakr (642$656 / 1244-1258)^{42}$. El significado de este nombre, a veces vocalizado también como Tā'zent ${ }^{43}$, es difícil de identificar, dado que la raíz $\sqrt{ } \mathrm{CZN}$ no está atestiguada en amazig y que el fonema africado faringal sonoro $/ \mathcal{S} /$ ( 'ayn) no es antiguo en esta lengua, si bien se pudo introducir en ella en esta época. Hipotéticamente, esta voz podría relacionarse con distintas raíces parecidas dotadas de sentidos despectivos: con el adjetivo ' $z z i$ ('negro') — que era aplicado con menosprecio a personas de color tanto en amazig como en árabe marroquí-; con la voz taghznt ('ogresa'), que podía hacer referencia a un aspecto determinado o defecto físico manifiesto de una mujer; o con el término ta 'nzult ('muda', 'mujer que tiene voz nasal'), considerando que la alternancia $[1] /[n]$ es bastante común en amazig. A estas interpretaciones cabe añadir la existencia del lexema izan/uzan ('repartir', 'dividir'), del que derivaría el término tazunt ('parte') ${ }^{44}$. Sea como fuere, consta que previamente una princesa almohade había respondido a esta denominación, que en el siglo XIV sería también portada por una de las hijas del emir meriní Abū 1-Hasan 'Alī (731-749/131331-1351) ${ }^{45}$.

Volviendo al referido emir 'Abd al-Haqq alMarīnī, su única hija documentada se llamaba Urțatlīm o Warțalīm (variante, según Miguel Ángel Manzano, de Urtațīm $)^{46}$. Esta denominación, más propia de la etnonimia que de la an-

40 En el presente artículo, reproduciremos las fechas de reinado de cada soberano mencionado tan solo en su primera referencia en el texto.

${ }^{41}$ Al-Anīs al-muțrib, p. 380.

42 Ibn al-Aḥmar, Rawdat al-nisrīn, p. 25, trad. Miguel Ángel Manzano, p. 25.

43 E incluso transcrito en árabe como Tà'zuna, Ibn al-Aḥmar, Al-Nafha al-nisrīniyya, p. 35.

44 Aghali-Zakara, "Néologie", pp. 8-9.

45 Ibn al-Ahmar, Rawdat al-nisrin, p. 36, trad. Miguel Ángel Manzano, p. 49, nota 153; Ibn al-Ahmar, Al-Nafha al-nisriniyya, p. 48.

46 Al-Dahīra al-saniyya, p. 22; Ibn al-Ahmar, Rawdat al-nisrīn, p. 25, trad. Miguel Ángel Manzano, p. 24; Manzano, “Onomástica benimerín”, p. 123. troponimia, estaba formada por una partícula de negación verbal o nominal $u r-/ w r-/ w r_{-}{ }^{47}$ ('sin') seguida de un verbo o de un sustantivo difícil de determinar bajo una raíz $\sqrt{T} L M$ o $\sqrt{D L M}$. Seguramente, podría corresponderse con el nombre atestiguado en la antigüedad en Calama (Numidia) como Wartilam o, tal vez, con el nombre moderno de un tipo de halcón, el halcón sacre (falco cherrug) que, según Mohamed Oussous $^{48}$, se llama warzllim ('el halcón') en tamazig. Aunque este zoónimo ya contiene el prefijo privativo lexicalizado, se puede identificar en él claramente la raíz $\sqrt{Z}$ LM ('estar pelado'), dado que esta ave rapaz es calva. Por otro lado, cabe señalar la existencia de una localidad llamada Beni Ourtilane (Banī Wartīlān) en la Kabilia argelina - tal vez relacionada con dicho nombre - cuya denominación ha sido desglosada como wer ('león')- dh ('y') - thihran ('leonas'), dadas las manadas de leones que habrían vivido allí en el pasado al abrigo de su terreno montañoso $^{49}$. De ser cierta esta versión, dicho nombre femenino también podría hacer referencia a este topónimo bereber de índole animal.

Entre el colectivo femenino de los Banū Marīn también figuran nombres bereberes femeninos hipocorísticos o abreviaturas de uso familiar, concentrados por lo general en los entornos familiares de emires que reinaron en la primera mitad del siglo XIV. El primero con el que nos tropezamos en las crónicas es el de Bazzū bint 'Uțān b. Muhammad b. 'Abd al-Haqq, esposa de Abū Ya' qūb Yūsuf (685-706/1286-1307) y madre del emir Abū Tāât 'Āmir (706-708/1307-1308) ${ }^{50}$. Esta fue una mujer noble (hurra) bereber perteneciente a la propia familia meriní, pues, como su cadena genealógica indica, era descendiente directa de 'Abd al-Haqq al-Marīnī. En cuanto a su nombre, se halla todavía en uso en las sociedades bereberes actuales bajo la forma $B z z a$.

De esta misma naturaleza serían las denominaciones de las hijas que tuvo el emir Abū l-Hasan 'Alī, llamadas respectivamente Tāmū, Zarrū y Sūna ${ }^{51}$. Respecto a la primera de ellas, debía

47 Chaker, "Onomastique berbère", p. 488.

48 Lexique animal, p. $27\left(\mathrm{n}^{\circ} 493\right)$ y p. $62\left(\mathrm{n}^{\circ} 1138\right)$

49 Véase <http://dictionnaire.sensagent.leparisien.fr/ Beni\%20Ourtilane/fr-fr/\#: :text=1\%2D\%20Beni\%20Ourtit lane $\% 20$ est $\% 20$ dit,un $\% 20$ anc $\%$ C3\%AAtre $\% 20$ vaillant $\% 20$ et $\% 20$ invincible $>$.

50 Ibn al-Ahmar, Rawḍt al-nisrīn, p. 32, trad. Miguel Ángel Manzano, p. 41; Ibn Abī Zar', Al-Anīs al-muțrib, p. 513; Manzano, "Onomástica benimerín”, p. 123.

51 Ibn al-Aḥmar, Raw dat al-nisrīn, p. 36, trad. Miguel Ángel Manzano, p. 49; Ibn al-Ahmar, Al-Nafha al-nisriniyya, p. 48. 
de corresponder a la voz Tamu, forma abreviada y berberizada del nombre árabe Fātima ${ }^{52}$. Otra posible interpretación de esta nomenclatura es Tamu, nombre femenino usado en amazig posiblemente procedente del tuareg Tamat ('variedad de acacia'). En cuanto a Zarrū, su inicial podría tratarse de una / $t /$ fricativa que se pronuncia como una $/ z /$ en diferentes variantes del tamazig, pudiendo corresponder con la voz $\mathrm{Ta}$ $r r u<$ Tarwa ('descendientes', 'hijos', 'progenitura'). En el caso de escribirse con /z/ sonora, podría provenir del nombre azaru ('compensación', 'aval', 'depósito') en un contexto de transacciones comerciales, si bien en algunas zonas Azaru también significa 'distancia'. Por último, el nombre de Sūna es difícil de localizar, pudiendo relacionarse muy hipotéticamente con la voz tasuna ('máscara'); una denominación que fue posteriormente impuesta a una hija del emir Abū 1-'Abbās Aḥmad (775-786/1373-1384; $789-796 / 1387-1393)^{53}$. En ello se siguió la costumbre de repetir nombres propios en el seno de un mismo linaje, hasta el punto de que algunos se acabaran convirtiendo en marcas onomásticas del mismo, calando incluso sus usos en la población del pueblo llano (al- 'àmma $)^{54}$.

Bereberes fueron también los nombres de algunas hijas del célebre emir Abū 'Inān Fāris (749-759/1348-1358), denominadas respectivamente con los hipocorísticos Zannū y Samā, y con el zoónimo de Ğandūza ${ }^{55}$. Si bien el significado del primero de ellos es difícil de precisar, pudo ser empleado entre los bereberes de las zonas de las montañas del Atlas marroquí, de quienes los judíos podían haberlo tomado prestado $^{56}$. Respecto al de Samā, tal vez podría corresponder con el nombre moderno de Sama. De Ğandūza podemos por último aducir varias interpretaciones: por un lado, podría significar 'la Becerra' o 'la Ternera' en tamazig tagnduzt, aunque está morfológicamente arabizado; por otro, también podría corresponder a la voz ganduz o genduz ('joven'), que por lo general se aplica únicamente a animales como cabras, vacas o camellos.

\footnotetext{
52 Manzano, “Onomástica benimerín”, p. 124.

53 Ibn al-Aḥmar, Rawdat al-nisrīn, p. 46, trad. Miguel Ángel Manzano, p. 74.

54 Felipe Rodríguez, Identidad y onomástica, p. 44.

55 Ibn al-Ahmar, Rawdat al-nisrīn, p. 39, trad. Miguel Ángel Manzano, p. 57; Ibn al-Ahmar, Al-Nafha al-nisriniyya, p. 52; Manzano, "Onomástica benimerín”, p. 124

56 Beider, "Jews of Berber Origin", p. 51, basándose en Taïf, Dictionnaire tamazight-français, p. 879.
}

Otra denominación bereber fue la de Tāma1lālt, portada por una esposa muwallada del recién referido Abū 'Inān Fāris, con la que tuvo a su hijo Abū Fāris Mūsà (786-788/1384-1386) ${ }^{57}$. Según define Lane ${ }^{58}$ en su Lexicon, el termino muwallada designaba a una mujer cuyo origen no era completamente árabe, pudiendo corresponder también una niña o joven esclava criada entre árabes. Por su parte, Miguel Ángel Manzano $^{59}$ definió igualmente esta voz ( $m$ uwallad/a) en el contexto social meriní, la cual hace referencia «tanto a hombres como a mujeres que no son árabes puros, esto es, aquellos cuyo nasab no es totalmente árabe», según definición de Ibn Manzūr en el diccionario Lisān al-'Arab. Volviendo al nombre de Tāmallālt, llama la atención la antítesis existente entre su significado en bereber, 'la Blanca' ${ }^{60}$ (en amazig, tamllalt), y los rasgos prosopográficos de la mujer que lo llevó, quien pudo ser morena de piel ya que se dice que la tez de su hijo tendía hacia esta tonalidad.

Por último, consta que también era bereber el nombre portado por una de las hijas del emir Abū 1-Ḥasan 'Alī, llamada Tāḥaḍrìt ${ }^{61}$. El significado de esta denominación podría ser 'la Coja', constituyendo pues un nombre propio concebido como laqab, es decir, como apodo o mote ${ }^{62}$. En este caso, divergiría en cuanto a su vocalización de la forma moderna tahidart (la secuencia $i$ - $a$ es por sí sola peyorativa) a partir de la raíz $\sqrt{ } \mathrm{DH}$ H. En amazig moderno subsiste como apellido (sobre todo en el Rif) en su forma masculina, Ahidar. Curiosamente, esta mujer aparece mencionada en las fuentes bajo una ambivalencia onomástica, pues los textos la mencionan tanto por su nombre bereber Tāhadurît como por su variante árabe, Hadriyya ('Alteza', 'Excelencia'). Ante todo, se trataba al parecer de un nombre de moda entre las mujeres bereberes de alta cuna en las sociedades

57 Ibn al-Aḥmar, Rawḍdat al-nisrīn, p. 47, trad. Miguel Ángel Manzano, p. 75; Ibn al-Ahmar, Al-Nafha al-nisriniyya, p. 66.

58 Lane, Arabic-English Lexicon, p. 2967.

59 Traducción de la Rawḍtat al-nisrīn de Ibn al-Aḥmar, p. 43 , nota 130 .

60 Manzano Rodríguez, trad. de la Rawdat al-nisrīn, p. 75 , nota 227 , donde señala la presencia de la marca gramatical del artículo en femenino.

61 Ibn al-Ahmar, Rawdat al-nisrīn, p. 36, trad. Miguel Ángel Manzano, p. 49, nota 152, quien remite a Ibn Haldūn, Histoire des berberes, trad. M. le Baron de Slane, IV, pp. 354355; Ibn al-Ahmar, Al-Nafha al-nisriniyya, p. 48; Manzano Rodríguez, "Onomástica benimerín”, p. 124.

${ }_{62}$ Cabe destacar cómo en otras culturas se dio este fenómeno, siendo un ejemplo de ello en latín el nombre de Claudia, de idéntico significado ('coja'), según apreciación de Carles Múrcia. 
magrebíes de la época, pues se tiene constancia de otras figuras que también lo portaron: tanto Ibn Haldūn (m. 808/1406) como la Crónica de Alfonso XI mencionan a un tal 'Askar Ibn Tāḥaḍrìt, cabeza de las tropas meriníes que en 1343 estaban asentadas en al-Andalus en tiempos del emir nazarí Yūsuf I (733-755/1333-1354) ${ }^{63}$; por su parte, se sabe de la existencia de una princesa zayyāní llamada Tāhaḍīt (m. 819/1416), hija del emir Abū Ḥammū Mūsà (II) (760-761/1358-1359), cuya sepultura e inscripción funeraria se conservan en Tremecén ${ }^{64}$.

\subsection{Los nombres islámicos de 'las Madres de los Creyentes' meriníes}

Las mujeres de la familia meriní también recibieron, como era de esperar, denominaciones árabes de muy distintos tipos en función de sus diferentes condiciones sociales, con las que esta dinastía trató de acreditar su alto nivel de arabización por las razones ya expuestas. Sin embargo, entre ellos los nombres propios tanto de las llamadas 'Madres de los Creyentes' musulmanes (ummahāt al-mu'mininn) como de las hijas del Profeta ${ }^{65}$ ocuparon un lugar fundamental, actuando como valores exponenciales de la profunda religiosidad islámica alcanzada por los Banū Marīn. Al igual que hicieron otras dinastías islámicas anteriores o coetáneas, los Meriníes tuvieron en consideración estas nomenclaturas femeninas, que otorgaron a sus descendientes o que portaron algunas mujeres que desposaron, con la intención de convertirlas en modelos de virtud análogos a los que dichas figuras emblemáticas de la historia del Islam representaban ${ }^{66}$.

El primer nombre, en términos de frecuencia de uso, empleado en su seno familiar fue el de ' $\bar{A}$ ' iša, vinculado a una de las figuras más destacadas de la tradición islámica: ' $\overline{\mathrm{A}}$ 'iša bint Abī Bakr (m. 58/678), la esposa preferida de Mahoma y, a su vez, hija del primer califa en la serie de los 'bien guiados' (al-hulafä' al-raši dūn) Abū Bakr al-Ṣiddīq (632-634) ${ }^{67}$. El signifi-

63 Ibn Haldūn, Histoire des berberes, p. 235; Manzano Rodríguez, La intervención de los Benimerines, pp. 269, 275, 276, 286, 299, 313 y 314.

64 Brosselard, Memoire épigraphique, pp. 28-30, trad. Estasen, P., "Revista de academia", p. 309; Barges, Complément de l'histoire, p. 229.

65 Sobre las hijas de Mahoma, véase la obra de la escritora egipcia 'Abd al-Raḥmān, 'Á' iša, más conocida como Bint alŠâți', The Daughters, y 'Alwānī, Al-Banāt.

66 Boloix Gallardo, "Virtue, Sanctity, and Charity".

${ }^{67}$ Sobre esta importante figura femenina islámica, véase cado de este nombre, procedente de la raíz 'āša ('vivir'), significa 'la Próspera' y 'la Viviente', sinónimo pues de al-hayya ('la viva') ${ }^{68}$. La gran trascendencia histórica y religiosa de esta figura femenina, considerada todo un referente en el Islam, hace que su nombre sea uno de los más habituales en el mundo islámico en general ${ }^{69}$. En cuanto al empleo de su denominación en época medieval, lo encontramos por lo general presente en los círculos suníes, pues fue evitado por los $s i$ 'íes por la tensa relación que aquella mantuvo tanto con la hija de Mahoma, Fāțima, como con su marido 'Alī̄o

Por su carácter islámico, la dinastía meriní hizo uso de esta denominación tan emblemática entre las mujeres musulmanas. El nombre de ' $\bar{A}$ ' iša, pronunciado en bereber como 'Iša, fue llevado por al menos por cuatro mujeres meriníes documentadas en las fuentes. Comenzando por el siglo XIII, fue portado por la segunda esposa que tomó el emir Abū Yūsuf Ya 'qūb (656-685/12581286), llamada ' $\bar{A}$ 'iša bint Muhalhil b. Yahyyà al-Halațī, mujer con la que engendró al octavo emir de la dinastía, Abū Sa 'īd 'Uțmān II (710731/1310-1331). De ella se nos dice que era noble (hurra) y árabe ('arabiyya), rasgo que encaja perfectamente con el empleo de esta denominación $^{71}$. Una centuria más tarde, también portarían dicha nomenclatura las hijas de los emires Abū 'Inān Fāris ${ }^{72}$ y Abū 1- Abbās Aḥmad ${ }^{73}$, respectivamente, así como la madre del emir Abū Zayyān Muhammad III (774-776/1372-1374), llamada 'Á' iša bint Fāriḥ 'el elche" ’74.

Otra nomenclatura representativa de las grandes mujeres del Islam llevada por las Meriníes fue la de Fāṭima, correspondiente a la celebérrima Fāțima al-Zahrā' (m. 11/633). Se trataba de la hija engendrada por Mahoma y su primera mujer, Hadīğa ${ }^{75}$, y esposa a la vez de 'Alī Ibn

Abbot, Aishah; asímismo, Bint al-Šăți', The Wives, pp. 55-98; Watt, “' $\bar{A}$ 'isha”, pp. 307-308; Spellberg, Politics.

68 Schimmel, Islamic names, pp. 20 y 43; Husayn, Mu '̌̆am, p. 358; Salahuddin, A Dictionary, p. 236.

69 Marín, "Cercanas a Dios", p. 47.

70 Schimmel, Islamic names, pp. 36 y 43; Boloix Gallardo, Las sultanas de la Alhambra, pp. 143-144.

${ }^{71}$ Ibn Abī Zar', Al-Anīs al-mutrib, p. 522; Ibn al-Aḥmar, Rawdat al-nisrīn, p. 34; Ibn al-Ahmar, Al-Nafha al-nisriniyya, p. 43.

72 Ibn al-Ahmar, Rawdat al-nisrīn, p. 39, trad. Miguel Ángel Manzano, p. 57; Ibn al-Ahmar, Al-Nafha al-nisriniyya, p. 52.

73 Ibn al-Ahmar, Rawdat al-nisrīn, p. 46, trad. Miguel Ángel Manzano, p. 74 y nota 222, quien indica otra posible lectura en otro manuscrito como Yāmina.

74 Ibn al-Aḥmar, Rawdat al-nisrīn, p. 44, trad. Miguel Ángel Manzano, p. 70; Ibn al-Ahmar, Al-Nafha al-nisriniyya, p. 63.

75 Watt, "KHadīija", p. 898. 
Abī Țālib (656-661), el cuarto califa 'bien guiado' (raššd d) e iniciador de la comunidad ši $i^{{ }^{76}}{ }^{6}$. El virtuosismo de esta mujer fue tal que llevó al Profeta a designarla tanto Sayyidat nisä' al-ğan$n a$ ('la Señora de las mujeres del paraíso') como Sayyidat nisā' al- 'alamīn ('la Señora de las mujeres de los dos mundos' $)^{77}$. Se trata de un nombre cuyas connotaciones semánticas, al margen de las religiosas, evidenciaban la gran importancia de la maternidad como principal papel femenino desde tiempos antiguos, pues significa 'Destetadora de [muchos] hijos' ${ }^{98}$. Considerando la gran veneración que esta figura inspiraba en la comunidad de creyentes musulmanes (al-umma), con este nombre fueron denominadas, al igual que en otros colectivos dinás$\operatorname{ticos}^{79}$, varias mujeres meriníes, en cuyo caso era pronunciado como Fațma, Fadna o Fazma en bereber ${ }^{80}$; en concreto, las hijas de los emires Abū 'Inān Fāris - la cual es calificada de piadosa (al-ṣăliḥa $)^{81}$ — Abū Zayyān Muḥammad II (763-767/1361-1365) $)^{82}$, Abū 1-'Abbās Aḥmad ${ }^{83}$ y Abū Fāris Mūsà ${ }^{84}$. Tal vez haya que relacionar incluso con esta denominación la de al-Zahrā' ('la Resplandeciente') ${ }^{85}$, que llevó una hija de Abū 1-Hasan 'Alī, como versión posiblemente abreviada de la de Fātima al-Zahrā' . Ante todo, el nombre de Fāṭima estuvo, al parecer, bastante presente en la sociedad fezí.

Otro nombre femenino sagrado de la tradición islámica presente en el árbol genealógico meriní fue el de Ruqayya ('ascenso', 'canto o recitación de palabras divinas', aunque también 'encantadora' ${ }^{86}$ ), pronunciado en bereber como

76 Veccia Vaglieri, "Fāțima", pp. 841-850.

77 Qutbuddin, "Fatima (al-Zahra)", p. 249.

78 Viguera Molíns, "Estudio preliminar", p. 26.

79 En el caso de la dinastía nazarí, hay al menos siete mujeres documentadas bajo este nombre desde el siglo XIII hasta el XV. Véase Boloix Gallardo, Las sultanas de la Alhambra, pp. 141-142.

80 Daaif, "Le nom propre”, p. 103.

81 Ibn al-Ahmar, Rawdat al-nisrīn, p. 39, trad. Miguel Ángel Manzano, p. 56; Ibn al-Ahmar, Al-Nafha al-nisriniyya, p. 52.

82 Ibn al-Aḥmar, Rawḍat al-nisrīn, p. 43, trad. Miguel Ángel Manzano, p. 67; Ibn al-Ahmar, Al-Nafha al-nisriniyya, p. 60

83 Ibn al-Ahmar, Rawdat al-nisrīn, p. 46, trad. Miguel Ángel Manzano, p. 74 y nota 222, quien indica otra posible lectura en otro manuscrito como Yāmina.

${ }^{84}$ Ibn al-Ahmar, Al-Nafha al-nisriniyya, p. 66; Ibn Abì Zar' al-Fāsī, al-Anīs al-mutrib, p. 317, afirma, seguramente por error, que la madre del emir Abū Yūsuf Ya' qūb se llamaba Fātima bint Yūsuf b. 'Abd al-Mu'min.

85 Ibn al-Ahmar, Rawdat al-nisrīn, p. 36, trad. Miguel Ángel Manzano, p. 49; Ibn al-Ahmar, Al-Nafha al-nisriniyya, p. 48

86 Salahuddin, A Dictionary, p. 315.
Rqiyya $^{87}$, cuya frecuencia de uso sigue al de Fātima en las sociedades bereberes medievales. Así se denominó otra de las hijas que Mahoma tuvo con Hadīğa, llamada Ruqayya bint Muhammad (m. 2/624), la cual luego se convertiría en la esposa de tercero de los califas rašš dūn, 'Uțān b. 'Affān (23-35/644-655). Tenemos constancia de sendas Ruqayyas meriníes: una hija de Abū 'Inān Fāris —que posteriormente sería desposada con el emir Abū l-'Abbās Aḥmad, con quien engendraría a Abū Zayyān Muhammad IV $(788 / 1386)^{88}$ - y una descendiente de Abū Fāris Mūsà ${ }^{89}$.

Bajo el nombre de Āmina ('digna de confianza'), correspondiente como es bien sabido a Āmina bint Wahb (m. c. 576), la madre del profeta Mahoma ${ }^{90}$, tenemos documentada a una hija del emir Abū l-'Abbās Aḥmad ${ }^{91}$. Procedente de la misma raíz semántica —amana, verbo que alberga los sentidos de 'fiarse de' y de 'confiar en' alguien - figura asimismo el nombre de Maymūna ('favorable', 'próspera', 'afortunada'), vinculado a Maymūna bint al-Ḥārit (m. 54/673), una de las esposas del Profeta convertida al Islam bajo esta denominación tan reveladora ${ }^{92}$. Esta fue otorgada a dos mujeres de la estirpe meriní: por un lado, a una de las hijas del emir Abū Sa 'īd 'Utimān (II) $)^{93}$ y, por otro, a una de las esposas de su sucesor, el emir Abū 1-Hasan 'Alī y madre de Abū 'Umar Tāšufìn (762-763/1361), la cual era precisamente una muwallada árabe ${ }^{94}$.

El nombre de otra de las esposas de Mahoma, Hafșa - relativo a Hafșa bint 'Umar (m. 45/665), hija del califa raš̀id 'Umar b. Hatțāb-,

87 Daaif, "Le nom propre", pp. 103-104, versión tamazig en la que se suprime la primera vocal del nombre y la tendencia a vocalizar en «i» la segunda vocal «a», como suele ser habitual en el caso de existir una yầ doble, especialmente en el caso de los diminutivos, como el que nos compete.

88 Ibn al-Aḥmar, Rawḍtat al-nisrīn, pp. 39 y 47, trad. Miguel Ángel Manzano, pp. 56 y 77; Ibn al-Ahmar, Al-Nafha al-nisriniyya, p. 52.

89 Ibn al-Ahmar, Al-Nafha al-nisriniyya, p. 66.

90 La escritora Bint al-Šătii' también escribió una monografía sobre esta figura, titulada The Mother of the Prophet, El Cairo, 1963, basada asimismo en fuentes árabes. Salahuddin, Ahmed, A Dictionary, p. 238.

${ }_{91}$ Ibn al-Ahmar, Rawdat al-nisrīn, p. 46, trad. Miguel Ángel Manzano, p. 74 y nota 222, quien indica otra posible lectura en otro manuscrito como Yāmina.

92 Salahuddin, A Dictionary, p. 287.

93 Ibn al-Ahmar, Rawdat al-nisrīn, p. 34, trad. Miguel Ángel Manzano, p. 46; Ibn al-Ahmar, Al-Nafha al-nisriniyya, p. 43.

94 Ibn al-Ahmar, Rawdat al-nisrīn, p. 42, trad. Miguel Ángel Manzano, p. 65; Ibn al-Ahmar, Al-Nafha al-nisriniyya, p. 59. Sobre todos estos nombres, véase Marín, Mujeres en al-Andalus, pp. 61-62. 
fue impuesto a una de las hijas del sultán meriní Abū Zayyān Muḥammad II ${ }^{95}$, significando en su origen 'cachorra de león'. Igualmente, consta que Abū l-Ḥasan 'Alī llamó a una de sus hijas Șafiyya ('Pura', 'Clara') ${ }^{96}$, a imagen de Șafiyya bint Huyayy al-Ahțab (m. 50/670 ó 52/672) ${ }^{97}$, esposa judía de Mahoma procedente de la tribu de los Banū 1-Nadịir de Medina que se convirtió al Islam. Aunque algo más alejado cronológicamente del entorno familiar del Profeta, está el nombre de Sukayna, diminutivo de Sakīna ('tranquilidad', 'serenidad de espíritu'), que llevó una de las hijas del imam al-Husayn b. 'Alī y, por tanto, una biznieta de Mahoma. Éste fue el elegido para otra hija de Abū 'Inān Fāris ${ }^{98}$.

Por último, y aunque no referido a una tradición onomástica propiamente islámica, consta que el emir Abū Sa'īd 'Utmān II tomó una esposa, también muwallada, llamada Maryam, que llegó a ser su favorita (haziyya) y con la que tuvo a su hijo Abū Fāris 'Abd al-'Azīz (796799/1393-1396 $)^{99}$. En cuanto a su significación, se inserta en la tradición onomástica bíblico-coránica, pues este es el nombre con el que los árabes se refieren a la virgen María en los textos sagrados del Islam, entre ellos el Corán ${ }^{100}$. Cabe señalar también su similitud con el de una de las esposas del Profeta, Māria bint Šim 'ūn (María, hija de Simón), quien curiosamente era una cristiana copta de Egipto $^{101}$. Según ciertas interpretaciones, este nombre podía significar 'la piadosa' ${ }^{102}$, si bien también se ha dicho que en lengua hebrea significaba 'don de Dios' (hibat Allāh $)^{103}$. Sin embargo, parece un hecho destacable que los bereberes tanto del Magreb como de al-Andalus no tuvieron una gran inclinación hacia el uso de denominaciones de este origen, tal vez, como explica Helena de Felipe, «por la falta de interés en una hipotética identificación

\footnotetext{
95 Ibn al-Ahmar, Rawḍat al-nisrīn, p. 43, trad. Miguel Ángel Manzano, p. 67; Ibn al-Ahmar, Al-Nafha al-nisriniyya, p. 60.

96 Ibn al-Aḥmar, Raw ḍat al-nisrīn, p. 36, trad. Miguel Ángel Manzano, p. 49; Ibn al-Ahmar, Al-Nafha al-nisriniyya, p. 48 .

97 Vacca y Roded, "Șafiyya".

98 Ibn al-Ahmar, Rawḍtat al-nisrīn, p. 39, trad. Miguel Ángel Manzano, p. 57; Ibn al-Ahmar, Al-Nafha al-nisriniyya, p. 52.

99 Ibn al-Ahmar, Rawḍat al-nisrīn, p. 43, trad. Miguel Ángel Manzano, pp. 67-68; Ibn al-Ahmar, Al-Nafha al-nisriniyya, p. 61 .

100 Salahuddin, A Dictionary, p. 287.

${ }_{101}$ Sobre esta figura, véase de nuevo Bint al-Šāți', The Wives of the Prophet Muhammad, pp. 201-216; Salahuddin, A Dictionary, p. 286.

102 Wensinck, y [Johnstone], "Maryam”, p. 628.

103 Ḥusayn, $M u$ ' ’̆am, p. 547.
}

con la población hispano-romana o las comunidades judías ${ }^{104}$. A pesar de ello, en el árbol genealógico meriní hallamos a la ya identificada Maryam, a la que las fuentes árabes ilustran como una mujer noble (hurra) profundamente islamizada, a pesar de ser una esclava liberta, como demuestra el hecho de que realizara la peregrinación a La Meca hacia el año 740 (1339) a instancias de su hijastro, el emir Abū 1-Ḥasan, quien le profesaba un gran afecto y respeto ${ }^{105}$.

\subsection{Las kunyas onomásticas: exponentes de maternidad, cualidad y dones divinos}

Dentro del catálogo de denominaciones árabes que algunas mujeres de la familia meriní recibieron, cabe mencionar también aquellos nombres formulados como kunyas onomásticas, uno de los signos más claros de arabización ${ }^{106}$. Estos siguieron el esquema 'Umm' + nombre propio/sustantivo, por lo general relativo a una cualidad o un don divino, binomio que podría traducirse bien como 'la madre de' un individuo citado a continuación, bien como 'la dotada de' la virtud subsiguiente ${ }^{107}$.

Distintas mujeres de esta dinastía respondieron a esta tipología de nombres, propia de la cultura islámica. Un ejemplo de ello es el de Umm al-Yumn ('la madre de la bendición' o 'la dotada de la prosperidad'), que portó Umm al-Yumn bint Muhallî al-Batțîwī o al-Batțū' î̀ ${ }^{108}$, la última esposa de 'Abd al-Haqq al-Marīnī, quien era de origen bereber como indica su nasab. Similar fue el nombre de Umm al-'Izz ('la madre de la gloria' o 'la dotada de la gloria') bint Muhammad b. Hāzim al- 'Alawīîn, correspondiente a la esposa del emir Abū Yūsuf Ya'qūb — madre, a su vez,

104 Felipe Rodríguez, Identidad y onomástica, p. 41. Sin embargo, cabe advertir cómo en un contexto dinástico colindante con el mundo cristiano como fue el de los Nazaríes de la península ibérica, el nombre de Maryam estuvo asociado a una mujer, hija del emir Ismā' 1 l I (713-725/1314-1325) y de su concubina cristiana 'Alwa; un hecho en el que, tal vez, podría verse cierta intención de reflejar el origen cristiano de su madre.

105 Boloix Gallardo, "Presencia", pp. 19-20; Boloix Gallardo, "Virtue, Sanctity, and Charity", pp. 328 y 332-333.

106 Marín, Mujeres en al-Andalus, p. 65.

107 Felipe Rodríguez, Identidad y onomástica, p. 452.

108 Ibn Abī Zar', Al-Anīs al-muțib, p. 388; Ibn al-Aḥmar, Raw dat al-nisrīn, pp. 25 y 27, trad. Manzano, pp. 25 y 30; Ibn al-Ahmar, Al-Nafha al-nisriniyya, p. 36. Sobre los orígenes familiares de esta mujer, véase Manzano Rodríguez, La intervención de los Benimerines, p. 227, nota 618.

109 Ibn Abī Zar' al-Fāsī, Al-Anīs al-muțib, pp. 445, 493 y 537; Ibn al-Aḥmar, Rawdat al-nisrīn, p. 30, trad. Miguel Ángel Manzano, p. 38; Ibn al-Ahmar, Al-Nafha al-nisriniyya, p. 36. 
de Abū Ya 'qūb Yūsuf-; un nombre que portaría también, ya en el siglo XIV, una de las hijas del emir Abū 1-Hasan 'Alīi110. Ambas denominaciones podrían tal vez relacionarse con las expresiones de al-yumn li-Llāh ('la bendición es de Dios') y al- 'izz li-Llāh ('la gloria es de Dios'), respectivamente, tan frecuentes en la epigrafía islámica medieval y presentes, en concreto, en la de algunas construcciones erigidas por la dinastía meri$\mathrm{ni}^{111}$. Estas y otras locuciones formaban parte de la llamada 'temática de la felicidad y bienestar' (thématique du bonheur et du bien-être) epigráfica, que comenzó a ser utilizada en arquitectura a partir de la época almohade $-y$, posteriormente, también en la nazarí-, y que implicaba la presencia divina manifiesta en la generosidad del soberano y explicitada en todos estos conceptos $^{112}$. En este sentido, los dones que expresaban estas jaculatorias podrían hacerse extensivos a las mujeres meriníes que portaron dichos nombres, como receptoras de la bendición y de la gloria que Dios concedía a dicha dinastía.

Bajo denominaciones parecidas figuran, igualmente, dos hijas del célebre emir Abū 'Inān Fāris, llamadas respectivamente Umm Hānī' ('la [Madre] de Hānī') y Umm al- 'Azīz ('la [Madre] de 'Azīz'), si bien de esta última se dice que era conocida bajo el apodo de Mindīla ('delantal', 'velo' o 'turbante') ${ }^{113}$. Igualmente, consta que una de las hijas que engendró tanto Abū 'Inān ${ }^{114}$ como Abū Zayyān Muhammad II ${ }^{115}$ y Abū l-'Abbās Ahmad ${ }^{116}$ respondían al nombre de Umm al-Farağ ('la madre de Farağ' o 'la dotada de la alegría').

Este último soberano engendró, por último, a una hija denominada Umm Umm al-Fath ('la

110 Ibn al-Ahmar, Rawḍat al-nisrīn, p. 36, trad. Miguel Ángel Manzano, p. 49; Ibn al-Ahmar, Al-Nafha al-nisriniyya, p. 48.

111 De hecho, algunas de ellas figuran en la decoración epigráfica de la necrópolis real meriní de Chella. Véase, a modo de ejemplo, Basset, y Lévi-Provençal, "Chella: une nécropole mérinide", p. 70; Cressier et al., "Un cas unique d'épure d'architecture en Occident islamique", pp. 14 y 26.

112 Martínez Enamorado, "Epigrafía meriní”, pp. 84-85; Martínez Núñez, "El proyecto almohade", pp. 139-157.

113 Ibn al-Ahmar, Rawdat al-nisrīn, p. 39, trad. Miguel Ángel Manzano, p. 57; Ibn al-Ahmar, Al-Nafha al-nisriniyya, p. 52, donde su nombre es ofrecido como Amat al- 'Azīz, nombre teóforo que tal vez tenga más sentido.

114 Ibn al-Aḥmar, Rawḍat al-nisrīn, p. 39, trad. Miguel Ángel Manzano, p. 57; Ibn al-Ahmar, Al-Nafha al-nisriniyya, p. 52.

115 Ibn al-Ahmar, Rawdat al-nisrīn, p. 43, trad. Miguel Ángel Manzano, p. 67; Ibn al-Ahmar, al-Nafha al-nisriniyya, p. 60.

116 Ibn al-Ahmar, Rawdat al-nisrīn, p. 46, trad. Miguel Ángel Manzano, p. 74. dotada de la conquista' o de 'la victoria') ${ }^{117}$, nombre cuyo análisis merece una especial atención en un contexto mucho más amplio, pues se trataba de una nomenclatura emblemática de las mujeres de la dinastía nazarí de Granada de los siglos XIV y XV, que trascendió a las crónicas cristianas castellanas como Omalfata u On Malfath $^{118}$. Esta denominación llevaba implícitas unas connotaciones militares triunfalistas, pues la victoria que exhortaba en nombre del Islam parecía derivada del propio espíritu de conquista y de triunfo que alentó en todo momento a los Banū Nașr, siempre en pie de guerra con los reinos cristianos peninsulares y, muy especialmente, con la cercana Corona de Castilla; de hecho, esta dinastía se sirvió de la raíz árabe $f-t-h$ en la construcción de su propio discurso triunfal como evidencia el análisis de muchas de sus manifestaciones oficiales ${ }^{119}$.

Volviendo al conjunto dinástico meriní, tal vez puede advertirse en la elección de este nombre por parte de Abū l-'Abbās Aḥmad una clara influencia de esta moda onomástica femenina granadina, posiblemente justificable en una serie de hechos que acreditan la especial cercanía que este emir tuvo con el reino nazarí: en primer lugar, consta el origen andalusí de la madre de dicho sultán meriní, de la que afirma Ibn al-Ahmar ${ }^{120}$ que era «una mujer libre, hija de un combatiente de la Guerra Santa [en al-Andalus] llamada Nuzha bint Abī 1- 'Abbās Haḍir b. Ab̄̄ 'Abd Allāh Muhammad al-Sibā'ì alQatḥānī al-Andalusī̀); por otro lado, el propio Abū l-'Abbās Aḥmad había nacido en Granada, concretamente en el año 756 (1355-56), según Ibn al-Aḥmar ${ }^{121}$; también, recordemos que el emir nazarí Muhammad V - que precisamente denominó a una de sus hijas Umm al-Fath ${ }^{122}$ había estado exiliado en la corte meriní de Fez entre los años 760-763 (1359-1362), un tiempo en el que esta pudo posiblemente acompañar a su padre al Magreb con el resto de su familia o, incluso, haber nacido en tierras meriníes. Por último, también es cierto que, tras su regreso a al-Andalus al recuperar el poder de la Alham-

117 Ibn al-Aḥmar, Rawḍt al-nisrīn, p. 46, trad. Miguel Ángel Manzano, p. 74.

118 Boloix Gallardo, Las sultanas de la Alhambra, pp. 145-146.

119 Boloix Gallardo, “¿Vencedores o vencidos?”, pp. 293-298.

120 Ibn al-Ahmmar, Rawḍtat al-nisrīn, p. 45, trad. Miguel Ángel Manzano, pp. 71-72.

121 Ibn al-Ahmar, Al-Nafha al-nisriniyya, p. 64.

122 Boloix Gallardo, Las sultanas de la Alhambra, p. 78. 
bra, el segundo reinado de Muhammad V (763793/1362-1391) fue en parte políticamente coetáneo al segundo gobierno de Abū 1-'Abbās Ahmad (789-796/1387-1393) ${ }^{123}$. Consta que dicha nomenclatura, que acabó siendo emblemática de las mujeres de la sociedad granadina nazarí, siguió estando presente en Fez en época watțāsí a través de familias granadinas exiliadas a dicha ciudad, como los Banū 1-Ğadd, emigrados allí a finales del siglo XV, entre los que se figuraba una mujer llamada Ummal-Fath bint 'Abd al-Wahhāb al-Kinānī'124.

\subsection{Otros nombres árabes: šuhras y epítetos onomásticos de esclavas y concubinas}

Por último, analizaremos los nombres árabes que recibieron algunas mujeres meriníes, a través de los cuales esta estirpe explicitó también tanto su grado de arabización como sus pretensiones de «arabidad». Distinguiremos, por un lado, aquellos que portaron algunas mujeres nobles sin entrañar, como en el apartado inmediatamente anterior, una significación religiosa $\mathrm{y}$, por otro, los «epítetos onomásticos» que les fueron impuestos a las concubinas tomadas por distintos emires de esta dinastía.

Comenzando por el primer elenco, hallamos que una de las esposas del fundador de la dinastía meriní, 'Abd al-Haqq al-Marīnī, se llamaba Sawt al-Nisā' ('el Azote de las mujeres'), nombre a modo de apodo (šuhra) que tal vez podría ser igualmente vocalizado como Sūt al-Nisầ'. Con esta mujer, de la que se dice que era descendiente de los jerifes de al-Husayn (šurafă husayniyyīn), engendró dicho soberano a sus vástagos 'Abd Allāh, Idrīs y Raḥhū ${ }^{125}$. Como al-Nuwwār bint Ṭāsalīit/Abī Bakr b. Hafṣ al-Wanyāsiniyya figura la segunda esposa que tomó este emir, una mujer bereber perteneciente a los Banū Yanğāsin, cuyo nombre significaba 'Flor, especialmente blanca'. Con ella tuvo a sus hijos 'Uțmān (I), el segundo emir meriní (614638/1217-1240), y Muhammad (638-642/1240$1244)^{126}$. Por su parte, tanto una hija de Abū

123 Boloix Gallardo, "Fés, point de rencontré", pp. 342-343.

124 Rodríguez Mediano, Familias de Fez, p. 146.

125 Ibn Abī Zar' al-Fāsī, al-Anīs al-mutrib, p. 403; alDahīra al-saniyya, p. 23; Ibn al-Aḥmar, Rawḍtal al-nisrīn, p. 25, trad. Manzano, p. 24; Manzano Rodríguez, “Onomástica benimerín", pp. 127-128, nota 33 .

126 Al-Dahīra al-saniyya, pp. 23 y 35; Ibn al-Ahmar, Rawḍat al-nisrīn, p. 25, trad. Manzano, p. 24; Ibn Marzūq, Al-Musnad, p. 112, trad. Viguera, p. 99. Boloix Gallardo, "Presencia e importancia", p. 15.
'Inān Fāris como de Abū Zayyān Muhammad II recibieron la peculiar denominación de Sitt al- 'Arab ('Señora o Dama de los árabes') '127, la cual era, al parecer, algo más frecuente en tierras del Egipto mameluco, pues así consta que se llamaban las esposas o hijas de algunas figuras destacadas de dicho reino ${ }^{128}$.

Pasando al ámbito de las esclavas destinadas al concubinato, estas recibieron, según era costumbre, nombres a gusto de su nuevo dueño que hacían referencia a sensaciones placenteras procedentes de campos semánticos muy diversos. En este sentido, los Meriníes no mostraron una gran originalidad, ya que otorgaron a sus esclavas nombres conocidos que, salvo excepciones, ya habían portado mujeres de dicha categoría en otros puntos y momentos de la historia del Islam.

Siguiendo el orden establecido en la catalogación que Manuela Marín ${ }^{129}$ hizo de este tipo de denominaciones, hallamos entre ellas nombres de animales, como los que recibieron Ġazzāla ('Gacela') ${ }^{130}$, concubina de Abū 'Inān Fāris, o Rīma ('Gacela blanca') ${ }^{131}$, hija de Abū 1-Hasan 'Alī. Este último caso resulta extraño al ser esta una denominación más propia de una esclava que de una hija, según los patrones onomásticos ya señalados; de hecho, Rīm ('Gacela blanca') se llamó una concubina del emir nazarí Yūsuf I (733-755/1333-1354), con quien engendró a su hijo Ismā'îl II (760-761/1359-1360) ${ }^{132}$. Igualmente, entre las Meriníes también figuran nomenclaturas relacionadas con el reino vegetal, tales como al-Yāsmīn ('el Jazmín') ${ }^{133}$, concubina de Abū 'Inān Fāris.

Otras esclavas respondieron a denominaciones relativas a fenómenos atmosféricos o as-

127 Ibn al-Aḥmar, Rawdat al-nisrīn, pp. 39 y 43, trad. Miguel Ángel Manzano, pp. 56 y 67; Ibn al-Ahmar, Al-Nafha al-nisriniyya, pp. 52 y 60; Manzano Rodríguez, “Onomástica benimerín", p. 123.

${ }_{128}$ Sirvan de ejemplo la hija de Badr al-Dīn Ibn 'Asākir o la esposa del jurista mameluco Šihāb al-Dīn Abū Šāma (m. 665/1368).

129 Marín, Mujeres en al-Andalus, pp. 66-69.

130 Ibn al-Aḥmar, Rawḍat al-nisrīn, p. 40, trad. Miguel Ángel Manzano, p. 60; Ibn al-Ahmar, al-Nafha al-nisriniyya, p. 54.

131 Ibn al-Aḥmar, Rawdat al-nisrīn, p. 36, trad. Miguel Ángel Manzano, p. 49; Ibn al-Ahmar, Al-Nafha al-nisriniyya, p. 48. Sobre el significado de este nombre, véase Salahuddin, A Dictionary, p. 313 y Ḧusayn, Mu'ğam, p. 211.

132 Boloix Gallardo, Las sultanas de la Alhambra, p. 74; Boloix Gallardo, "Beyond the Haram”, pp. 396-399.

133 Ibn al-Ahmar, Rawdat al-nisrīn, p. 41, trad. Miguel Ángel Manzano, p. 61; Ibn al-Ahmar, Al-Nafha al-nisriniyya, p. 55. 
tronómicos, siendo el caso de las dos concubinas (ummahāt al-awlād) cristianas (rūmiyyāt) que tomó este último soberano ${ }^{134}$, llamadas respectivamente Šams al-Duhà ('Sol de la mañana') ${ }^{135}$ y Qamar ('Luna')'136. Ambos nombres ya gozaban de un destacado uso entre mujeres esclavas de la historia del Islam. Bajo el nombre de Šams al-Duhà está documentada, de hecho, una concubina del emir nazarí Muhammad II (671-701/1273-1302) $)^{137}$. Por su parte, el nombre simple de Šams ('Sol') —del que están documentadas variantes como Šams $1^{138}$ y $\breve{S}{ }^{2} \mathrm{sa}^{139}$ - estaba especialmente vinculado en al-Andalus (sobre todo, en la dinastía nazarí1 ${ }^{140}$ ) con mujeres procedentes del área cristiana de la península ibérica; de hecho, así se llamaba la madre del califa almohade Abū 1-'Alā' Idrīs (624-630/1227-1232), la cual era precisamente «una concubina cristiana» (umm al-walad rūmiyya $)^{141}$. En realidad, podría tratarse de una traducción del castellano al árabe del nombre cristiano 'Sol' - al que supuestamente respondió una de las hijas del Cid Campeador-, el cual, según Jack Weiner ${ }^{142}$, no era «medieval sino clásico, es decir, mitológico» ${ }^{143}$. Considerando que las hijas del Cid eran 'blancas como el sol' ${ }^{144}$, tal vez la aplicación de esta nomenclatura respondiese a la intención de reflejar los rasgos físicos claros y rubios que pudieron tener las mujeres que lo portaron.

134 Ibn al-Ahmar, Rawḍt al-nisrīn, p. 36, trad. Miguel Ángel Manzano, p. 49; Ibn al-Ahmar, al-Nafha al-nisriniyya, p. 43.

135 Ibn al-Ahmar, Rawdat al-nisrin, p. 37, trad. Miguel Ángel Manzano, p. 53; Ibn al-Ahmar, Al-Nafha al-nisriniyya, p. 51.

136 Ibn al-Ahmar, Rawdat al-nisrīn, p. 41, trad. Miguel Ángel Manzano, p. 62; Ibn al-Ahmar, Al-Nafha al-nisriniyya, p. 49.

137 Boloix Gallardo, Las sultanas de la Alhambra, pp. 58-59; Boloix Gallardo, “Beyond the Haram”, p. 391.

138 Nombre habitual entre las mozárabes toledanas, documentado en un epitafio de una mujer mozárabe llamada precisamente Šamsī ibnat Ibn al-Šayh hallado en Toledo, de principios de la época almohade (año 1160), estudiado por Lévi-Provençal, Inscriptions arabes d'Espagne, p. 79, $\mathrm{n}^{\mathrm{o}} 82$; Martínez Núñez, "Las fuentes epigráficas", p. 65.

139 Recogido por Husayn, $M u$ ' ‘̆am, p. 308.

140 Boloix Gallardo, Las sultanas de la Alhambra, pp. 51-53, 60, 74, 154; Boloix Gallardo, "Beyond the Haram", pp. 390-391.

141 Ibn Abī Zar', Al-Anīs al-mutrib bi-Rawḍ al-qirțās, p. 341 .

142 Weiner, El Poema de Mío Cid, p. 107.

143 Cabe destacar que Ḥusayn, Mu '̌̆am, p. 308, recoge en la entrada de este nombre otra versión femenina del mismo nombre, Šamsa.

144 Weiner, El Poema de Mío Cid, p. 107.
En cuanto a Qamar, su uso fue todavía más frecuente entre mujeres esclavas; en concreto, consta que así se llamaron las concubinas que tomaron, respectivamente, el emir almorávide 'Alī b. Yūsuf (500-537/1107-1143) $)^{145}$ y el sultán nazarí Ismā'̄il I (713-725/1314-1325) ${ }^{146}$. Este nombre responde a la voz genérica árabe para referir a la luna, siendo en poesía árabe clásica una recurrente metáfora con la que los poetas describían el rostro radiante de la amada, el que, tal vez, pudo tener la concubina meriní que lo llevaba.

Por su parte, hubo mujeres que recibieron denominaciones de materiales preciosos o altamente valorados, más originales que los anteriores: así sucedió con al- 'Anbar ('el Ámbar') $)^{147}$, concedido a una esclava negra abisinia ('abašiyya) de Abū Sa'îd 'Uțmān II (710-731/1310-1331), cuyo nombre hacía referencia a una sustancia muy apreciada en el Oriente islámico por generar un perfume de agradable aroma ${ }^{148}$. Resulta llamativo que esta nomenclatura fuese aplicada a una mujer, puesto que generalmente era impuesta a esclavos varones de la historia del Islam ${ }^{149}$. En este ámbito se inscribe también el nombre de Fiḍda ('Plata') ${ }^{150}$, muwallada árabe que tomó Abū Zayyān Muhammad II, o al-Ğawhar ('la Joya') ${ }^{151}$, esclava de Abū 1-'Abbās Aḥmad y madre de Abū Fāris 'Abd al- 'Azīz, Abū 'Āmir 'Abd Allāh (799-800/1396-1397) y Abū Sa' $\bar{i} d$ Uțmān III (800-823/1398-1420), mujer por

145 Marín, Mujeres en al-Andalus, pp. 588 y 589.

146 Boloix Gallardo, Las sultanas de la Alhambra, pp. 71-72.

147 Ibn al-Ahmar, Rawdat al-nisrīn, p. 35, trad. Miguel Ángel Manzano, p. 48; Ibn al-Ahmar, al-Nafha al-nisriniyya, p. 47; Ibn Marzūq, El Musnad, pp. 199-202, Ibn Haldūn, Kitāb al- 'ibar, vol. VII, p. 288; y ed. Būlāq, VII, p. 267 y la Gran Crónica de Alfonso XI, vol. II, cap. CCXXXV, p. 231, apud Manzano Rodríguez, "Biografías y poder político", p. 254 y nota 2. Sobre esta mujer, véase Boloix Gallardo, "Presencia e importancia", pp. 15-19y "Virtue, Sanctity, and Charity", p. 323.

148 Ruska y Plesner, "Anbar”, en EI , vol. I, p. 484; Rāgib, "Esclaves et affranchis", p. 247.

149 Agradezco a mi compañero Mohamed Meouak (Universidad de Cádiz) las siguientes referencias bibliográficas que generosamente me ha facilitado para acreditar el uso onomástico masculino del nombre de 'Anbar en las sociedades islámicas medievales: Ayalon, "The eunuchs”, pp. 267-295; Marmon, Eunuchs \& Sacred Boundaries, pp. 71-72; Meouak, Saqāliba, p. $173, n^{\circ} 43$. Véase también Tolmacheva, "Concubines on the Road", pp. 163-189.

150 Ibn al-Aḥmar, Raw dat al-nisrīn, p. 43, trad. Miguel Ángel Manzano, p. 66; Ibn al-Ahmar, Al-Nafha al-nisriniyya, p. 60 .

151 Ibn al-Aḥmar, Raw dat al-nisrīn, pp. 50-51, trad. Miguel Ángel Manzano, pp. 81-82, 84 y 85. 
Tabla 1: Clasificación lingüístico-cultural de los nombres de las mujeres reales meriníes.

\begin{tabular}{|c|c|c|c|c|c|}
\hline Nombre $(*$ : concubina) & Bereber & Islámico & Árabe & Otro origen & Frecuencia de uso \\
\hline Tā'zūnt/ Tā'zent & $\mathrm{x}$ & & & & 2 \\
\hline Urțatlīm / Warțalīm & $\mathrm{x}$ & & & & 1 \\
\hline Bazzū & $\mathrm{x}$ & & & & 1 \\
\hline Tāmū & $\mathrm{x}$ & & & & 1 \\
\hline Zarrū & $\mathrm{x}$ & & & & 1 \\
\hline Sūna & $\mathrm{x}$ & & & & 2 \\
\hline Zannū & $\mathrm{x}$ & & & & 1 \\
\hline Samā & $\mathrm{x}$ & & & & 1 \\
\hline Ğandūza & $\mathrm{x}$ & & & & 1 \\
\hline Tāmallālt & $\mathrm{X}$ & & & & 1 \\
\hline Tāḥaḍrīt/ Haḍriyya & $\mathrm{x}$ & & $\mathrm{x}$ & & 1 \\
\hline ' $\bar{A}$ ' iša & & $\mathrm{x}$ & & & 4 \\
\hline Fāțima & & $\mathrm{x}$ & & & 4 \\
\hline Ruqayya & & $\mathrm{x}$ & & & 2 \\
\hline $\bar{A} \operatorname{mina}$ & & $\mathrm{x}$ & & & 1 \\
\hline Maymūna & & $\mathrm{x}$ & & & 2 \\
\hline Hafșa & & $\mathrm{x}$ & & & 1 \\
\hline Șafiyya & & $\mathrm{x}$ & & & 1 \\
\hline Sukayna & & $\mathrm{x}$ & & & 1 \\
\hline Maryam & & & & $\mathrm{x}$ & 1 \\
\hline Umm al-Yumn & & & $\mathrm{x}$ & & 1 \\
\hline Umm al-'Izz & & & $\mathrm{x}$ & & 2 \\
\hline Umm Hānì & & & $\mathrm{x}$ & & 1 \\
\hline Umm al-'Azīz & & & $\mathrm{x}$ & & 1 \\
\hline Umm al-Farağ & & & $\mathrm{x}$ & & 3 \\
\hline Umm al-Fath & & & $\mathrm{x}$ & & 1 \\
\hline Sawț al-Nisā' & & & $\mathrm{x}$ & & 1 \\
\hline Al-Nuwwār & & & $\mathrm{x}$ & & 1 \\
\hline Sitt al-'Arab & & & $\mathrm{X}$ & & 2 \\
\hline Ġazzāla* & & & $\mathrm{x}$ & & 1 \\
\hline Rīma* & & & $\mathrm{X}$ & & 1 \\
\hline Al-Yāsmīn & & & $\mathrm{x}$ & & 1 \\
\hline Al-Zahrā' & & & $\mathrm{x}$ & & 1 \\
\hline Šams al-Ḍuhà* & & & $\mathrm{x}$ & & 1 \\
\hline Qamar* & & & $\mathrm{x}$ & & 1 \\
\hline Al-'Anbar* & & & $\mathrm{X}$ & & 1 \\
\hline Fiḍda* & & & $\mathrm{x}$ & & 1 \\
\hline Al-Ğawhar* & & & $\mathrm{X}$ & & 1 \\
\hline Yāmina & & & $\mathrm{x}$ & & 1 \\
\hline Zayāna & & & $\mathrm{x}$ & & 1 \\
\hline 'Asīla" & & & $\mathrm{x}$ & & 1 \\
\hline Nuzha & & & $\mathrm{x}$ & & 1 \\
\hline
\end{tabular}

cuya excelencia era definida como 'el velo sublime' (al-hiğāa al- 'ālù).

Otras esclavas fueron llamadas con nombres referidos a rasgos físicos o morales, entre las que destacan Yāmina'152 ('Afortunada', 'Dichosa'), hija de Abū 1-Ḥasan 'Alī; Zayāna ('Bella'),

${ }_{152}$ Trad. Miguel Ángel Manzano, p. 49, ya que Ibn al-Ahmar, Rawdat al-nisrīn, lo omite en la p. 36; Ibn al-Ahmar, Al-Nafha al-nisriniyya, p. 48. otorgado a la segunda esposa de Abū Ya'qūb Yūsuf, seguramente debido a su apariencia hermosa, quien era una muwallada de etnia árabe ('arabiyya/min tālid al- 'arab) '153; o 'Asīla ('Me-

153 Ibn al-Ahmar, Rawdat al-nisrīn, p. 33; Ibn al-Ahmar, Al-Nafha al-nisriniyya, p. 42, cuyo editor ha leído el nombre de esta mujer como Zabāna, versión que no parece muy convincente; Ibn Abī Zar', Al-Anīs al-muțrib, p. 518. 
lada') $)^{154}$, esclava (ama) madre del emir Abū Zayyān Muhammad V (788-789/1386-1387), quien tal vez fue así denominada bien por su tono de piel color miel - pues debía de ser negra, rasgo que precisamente adjudican las crónicas a dicho soberano (aswad al-lawn) - bien por su carácter dulce. Por último, también figura un nombre femenino referente a una cualidad abstracta, Nuzha ('Paseo', 'Recreo', 'Placer') bint Abī l-'Abbās Haḍir b. Abī 'Abd Allāh Muḥammad al-Sibā' '̄ al-Qaḥtān̄̄ al-Andalusī, esposa noble (al-hurra) de origen andalusí del emir Abū Sālim Ibrāhīm (760-762/1359-1361) ${ }^{155}$. Un nombre con el que aparecen documentadas otras mujeres andalusíes, tales como una bailarina malagueña del s. XII ${ }^{156}$ o la esposa legítima del ya mencionado emir nazarí Muḥammad II ${ }^{157}$.

\section{Conclusiones}

A lo largo de las páginas previas se ha podido comprobar cómo el análisis filológico y socio-cultural de la onomástica de las mujeres de la dinastía meriní constituye un elemento de gran utilidad para profundizar en el estudio de distintas facetas de esta estirpe: por un lado, para reconstruir los diversos rasgos identitarios (étnicos, culturales, geográficos, religiosos, etc.) tanto de aquellas como de los soberanos con los que se relacionaron en distintas calidades familiares (madres, hermanas, esposas, concubinas, hijas, etc.); $\mathrm{y}$, por otro, para definir con una mayor precisión las estrategias de legitimación político-religiosa que los Meriníes desarrollaron sobre dos principales pilares: unas supuestas raíces árabes, berberizadas mediante una legendaria familiaridad ancestral con la cultura bereber, y una profunda islamización. Como se ha pretendido demostrar, la onomástica femenina constituyó un indicio exponencial de ambos fenómenos y estuvo expresada en ambas lenguas -árabe y bereber - tanto respectiva como paralelamente, pues en algunos casos advertim os nomenclaturas femeninas expresadas a la vez en dichos idiomas (como sucede en Tâḥaḍrīt/Haḍriyya o en Tāmū/Fāțima). Los nombres de mujer meriníes fueron, pues,

154 Ibn al-Aḥmar, Rawḍat al-nisrīn, p. 48, trad. Miguel Ángel Manzano, p. 79; Ibn al-Ahmar, Al-Nafha al-nisriniyya, p. 67.

155 Ibn al-Ahmar, Rawḍat al-nisrīn, p. 45, trad. Miguel Ángel Manzano, pp. 71-72; Ibn al-Ahmar, Al-Nafha al-nisriniyya, pp. 63-64.

156 Marín, Mujeres en al-Andalus, pp. 60 y 300, 648.

157 Boloix Gallardo, Las sultanas de la Alhambra, pp. partícipes de sendas culturas aunque estuvieron enmarcados, en la mayoría de las ocasiones, en las tradiciones onomásticas de la propia historia social del Islam.

Según se desprende de este estudio, desde el siglo XIII en adelante las mujeres meriníes recibieron tanto nombres bereberes como árabes, aunque en distintas proporciones. Los primeros, aunque bastante más escasos que los segundos, dejaron traslucir el peso de la etnia y la cultura amazig que los Meriníes tenían, a pesar de sus reticencias a manifestarlo. Por lo general, estas nomenclaturas bereberes fueron portadas por tres esposas legítimas de algunos emires pero, sobre todo, por un total de diez hijas de estos, advirtiéndose pues un beneplácito hacia la transmisión, de generación en generación, de la cultura bereber meriní dentro de su tronco familiar. Sin embargo, es difícil hablar de «tradiciones onomásticas» propiamente dichas en la imposición de estos nombres; y es que, salvo en el caso de Tā'zūnt/ Tā'zent y de Sūna - empleados respectivamente en dos ocasiones - no se advierten repeticiones de otras denominaciones femeninas en tamazig documentadas en esta familia.

En cuanto a los nombres árabes, estos compensaron la presencia de los anteriores en el árbol genealógico de los Banū Marīn, siendo su frecuente adopción especialmente necesaria para consolidar la supuesta «arabidad» de su identidad cultural. Entre los más importantes figuran los nombres islámicos, correspondientes, como ya ha sido expuesto, a las 'Madres de los creyentes' musulmanes. Siguiendo en ello el mismo comportamiento que otras muchas dinastías, los Meriníes los impusieron con gran asiduidad, siendo portados por tres esposas legítimas - tanto de etnia árabe como muwalladas $\mathrm{e}$, incluso, de origen elche- $\mathrm{y}$, sobre todo, por trece hijas de distintos emires; mujeres, sobre todo estas últimas, que quedaban destinadas a convertirse en los modelos de virtud representados por aquellas figuras emblemáticas de la historia del Islam, que luego transmitirían a sus hijos. El empleo, en una única ocasión, de un nombre de tradición bíblica como el de Maryam tan vez denote, por el contrario, una intención consciente de evitar una identificación de esta familia bereber tanto con la sociedad hispano-romana precedente como con la cultura cristiana circundante.

Por otro lado, otras mujeres recibieron nombres árabes desprovistos de implicaciones semánticas religiosas, tales como las kunyas ono- 
másticas —que fueron portadas tanto por dos esposas nobles de indistinto origen bereber y árabe, como especialmente por siete descendientes de soberanos meriníes-. En el seno de esta dinastía, el valor de estas fórmulas nominales transciende sus propios matices implícitos de maternidad y de cualidad, pudiendo incluso vincularse íntimamente con los dones divinos invocados en las locuciones presentes en la epigrafía de la edilicia meriní, heredera en muchas de sus expresiones de la almohade. Tal vez por esta motivación constituyeron nombres bastante frecuentes en la familia que nos ocupa, reiterándose su imposición en algunos casos hasta en dos - caso de Umm al-'Izz - y en tres ocasiones — caso de Umm al-Farağ - . La presencia de un nombre femenino tan nazarí como el de Umm al-Fath en el árbol familiar meriní constata la estrecha relación político-social existente entre ambos reinos a lo largo de sus paralelas trayectorias, así como la fuerte implicación de Fez en los asuntos gubernamentales de Granada.

Por último, cabe detenerse brevemente en aquellas denominaciones concebidas a modo de šuhras y de «epítetos onomásticos» que otras mujeres de la dinastía meriní recibieron. En el caso de los primeros, la asignación de estos apodos no hace distinción entre esposas de supuesto origen árabe o bereber, siendo aplicados en ambos casos. La reiteración del nombre Sitt al-'Arab, frecuente en tierras mamelucas, tal vez evidencia una fluida relación de los Meriníes con dicho reino. Respecto a la adopción de los segundos, sí resulta algo desconcertante pues, aunque su imposición fue frecuente en esclavas destinadas al concubinato - computándose hasta ocho casos en mujeres de distintas procedencias (cristiana peninsular, negra africana)—, según era la norma habitual, sorprendentemente también aparece aplicado a dos esposas legítimas (ambas, muwalladas árabes), a una de origen andalusí e, incluso, a tres hijas de sultanes de la dinastía. A pesar de esta peculiaridad, los Meriníes no mostraron una gran originalidad en la elección de dichos nombres que, salvo excepciones, ya habían portado concubinas de otros contextos dinásticos de la historia del Islam.

Sea como fuere, lo cierto es que los Meriníes se sirvieron de las denominaciones de sus mujeres para perfilar con una mayor precisión muchos rasgos de su propia identidad como dinastía.

\section{Fuentes}

Al-DQhīra al-saniyya fì ta'rīh al-dawla al-Marīniyya, 'Abd al-Wahhāb Ibn Manșūr (ed.), Rabat, Dār alManșūr li-1-Ṭibā'a wa-l-Wirāqa, 1972.

El Corán, Julio Cortés (trad.), Barcelona, Herder, 1998. Gran Crónica de Alfonso XI, D. Catalán (ed.), Madrid, 1977. Ibn Abī Zar' al-Fāsī, Al-Anīs al-mutrib bi-Rawḍ al-qirțās fì ahbār mulūk al-Magrib wa-ta'rīh madīnat Fās, 'Abd al-Wahhāb Ibn Manșūr (ed.), Rabat, Al-Maṭba 'a al-Mulkiyya $1999^{2}$.

Ibn al-Aḥmar, Rawụtat al-nisrīn fì dawlat Ban̄̄ Marīn, 'Abd al-Wahhāb Ibn Manșūr (ed.), Rabat, Al-Mațba 'a al-Mulkiyya, 1991; Miguel Ángel Manzano (trad.), Madrid, CSIC, 1989.

Ibn Haldūn, Kitāb al- 'ibar, Beirut, 1992; M. le Baron de Slane (trad.), Histoire des berberes et des dynasties musulmanes de l'Afrique septentrionale, Argel, Imprimerie du Gouvernement, 1856.

Ibn al-Hुațīb, Al-Ihāṭa fì aḩbār Garnāṭa, Muḥammad 'Abd Allāh 'Inān (ed.), El Cairo, Maktabat al-Ḩānğī, 2001, vol. I.

Ibn Marzūq, Al-Musnad al-ṣaḥ̄h al-ḥasan fì ma'ātir mawlānā Abī l-Hasan, M. Jesús Viguera Molíns (ed.), Argel, 1981 (reimpreso en Argel: 2007; reimpr. Rabat: Dār al-Amān, 2013); M. a Jesús Viguera Molíns (trad.), El Musnad: hechos memorables de Abu l-Hasan, sultán de los Benimerines, Madrid, Instituto HispanoÁrabe de Cultura, 1977.

Ibn Sa d, Kitāb al-țabaqāt al-kabīr, vol. II; 'A' iša Bewley (trad.), The Men of Madina, Londres, Ta-Ha Publishers, 2000; vol. VIII, 'A' iša Bewley (trad.), The Women of Madina, Londres, Ta-Ha Publishers, 1995.

\section{Bibliografía}

Abbot, Nabia, Aishah, the Beloved of Muhammad, Chicago, University of Chicago Press, 1942.

Aghali-Zakara, Mohamed, "Néologie et données culturelles en berbère. Éléments de terminologie mathématiques en tuaregh", en Salem Chaker y Andrzej Zaborski (eds.), Études berbères et ChamitoSémitiques. Mélanges offerts à Karl-G. Prasse, París, Peeters, 2000, pp. 1-13.

'Alwān̄i, Našwa, Al-Banāt fì bayt al-nubuwwa: Zaynab. Ruqayya, Umm Kultūm, Fāțima, Damasco, Maktabat al-Fārārbī, 1999.

Ayalon, David, "The eunuchs in the Mamluk Sultanate", en Myriam Rosen-Ayalon (ed.), Studies in memory of Gaston Wiet, Jerusalén, The Hebrew University of Jerusalem, 1977, pp. 267-295.

Basset, R. y [Pellat, Ch.], "Berbers", en H.A.R. Gibb, J.H. Kramers, E. Lévi-Provençal y J. Schacht (eds.), Encyclopaedia of Islam. Second Edition, Leiden, Brill, 1979, vol. I, pp. 1173-1187. 
Basset, Henri y Lévi-Provençal, Evariste, "Chella: une nécropole mérinide”, Hesperis, 2 (1922), pp. 1-92.

Beider, Alexander, "Jews of Berber Origin? Myth or Reality", Hamsa. Journal of Judaic and Islamic Studies, 3 (2016-2017), pp. 38-61.

Bennison, Amira K., "Morocco", en Joseph Suad (ed.), Encyclopedia of Women \& Islamic Cultures, LeidenBoston, Brill, 2007, pp. 334-336.

Bint al-Šăti', The Daughters of the Prophet, El Cairo, Al-Šarika al- Arabiyya, 1959.

Bint al-Šătị', The Mother of the Prophet, El Cairo, AlŠarika al-'Arabiyya, 1963.

Bint al-Šăți', The Wives of the Prophet, Sh. Muhammad Ashraf, Lahore, 1971.

Boloix Gallardo, Bárbara, Las sultanas de la Alhambra. Las grandes desconocidas del Reino Nazari de Granada (siglos XIII-XV), Granada, ComaresPatronato de la Alhambra y el Generalife, 2013.

Boloix Gallardo, Bárbara, "Beyond the Haram: Ibn al-Khațīb and his Privileged Knowledge of Royal Nasrid Women", Medieval Encounters, 20 (2014), pp. 384-403.

Boloix Gallardo, Bárbara, "Fés, point de rencontre entre sultanes nasrides et mérinids, en Fes, 1200 ans d'Histoire", en Jerónimo Páez y Hamid Triki (ed.), Fés, L'âme du Maroc. Douze siècles d'histoire, Granada, Fondation Benjelloun Mezian, 2015, pp. 330-345.

Boloix Gallardo, Bárbara, "Presencia e importancia de la mujer en el Musnad de Ibn Marzūq al-Tilimsān̄̄", Anaquel de Estudios Árabes, 27 (2015), pp. 7-28.

Boloix Gallardo, Bárbara, “¿Vencedores o vencidos? Claves del discurso triunfalista nazarí en tiempos de «Reconquista»", en Carlos de Ayala Martínez, Isabel C. Ferreira Fernandes y J. Santiago Palacios Ontalva (coords.), Las Reconquista. Ideología y justificación de la Guerra Santa peninsular, Madrid, La Ergástula, 2019, pp. 281-302.

Boloix Gallardo, Bárbara, "Virtue, Sanctity, and Charity of the Royal Women of Fez; The 'Mothers of the Believers' of the Merinid Dynasty", Hawwa, 19, (2021), pp. 314-338.

Boloix Gallardo, Bárbara, "Los harenes del mundo islámico medieval y su pervivencia romántica en el norte de África", en Catálogo de la Exposición «Odaliscas. De Ingres a Picasso», Granada, Patronato de la Alhambra y el Generalife, 2021 (en prensa).

Brosselard, M. Charles, Memoire épigraphique et historique sur les tombeaux des émires Beni-Zeiyan, et de Boabdil, dernier roi de Grenade, découverts à Tlemcen, París, Impremirie Nationale, 1876.

Calasso, Giovanna, "Arabi e berberi nel «Rawd al-qirțās» di ibn Ab̄̄ Zar : ancora sulle origini di Fez”, Egitto e vicino Oriente, 6 (1983), pp. 333-350.
Chaker, Salem, "Onomastique berbère ancienne (Antiquité/Moyen Âge): rupture et continuité", Bulletin Archéologique du Comité des travaux historiques et scientifiques, 19 (1983) pp. 483-497.

Corriente, Federico, Diccionario árabe-español, Barcelona, Herder, 1991.

Cory, Stephen, "Honouring the Prophet's Family", in Amira K. Bennison (ed.), The Articulation of Power in Medieval Iberia and the Maghrib, Oxford, Oxford University Press, 2014, pp. 107-124.

Cressier, Patrice et al., "Un cas unique d'épure d'architecture en Occident islamique. La représentation de l'arc et du décor de la grande porte mérinide de Šālla (Rabat)", Arqueología de la Arquitectura 18, (2021),e116. https://doi.org/10.3989/arq.arqt.2021.008.

Daaï, Lahcen, "Le nom propre berbère (modèle tachelhil). Réflexion générale sur ses caractéristiques de base", Hamsa. Journal of Judaic and Islamic Studies, 3 (2016-2017), pp. 101-112.

El Hour, Rachid, "Reflexiones acerca de las dinastías bereberes y lengua bereber en el Magreb medieval", Miscelánea de Estudios Árabes y Hebraicos. Sección Árabe-Islam, 64 (2015), pp. 45-59.

Estasen, P., "Revista de academia extranjeras", Revista Histórica, 3 (1876), pp. 303-313.

Felipe Rodríguez, Helena de, Identidad y onomástica de los bereberes de al-Andalus, Madrid, CSIC, 1997.

Felipe Rodríguez, Helena de, "Leyendas árabes sobre el origen de los bereberes”, Al-Qanțara, 11 (1990), pp. 379-396.

Fierro, Maribel, "Las genealogías de 'Abd al-Mu'min, primer califa almohade", Al-Qanțara, 24, 1 (2003), pp. 77-107.

Gabrieli, F., "Al-Khansā”, en H.A.R. Gibb, J.H. Kramers, E. Lévi-Provençal y J. Schacht (eds.), Encyclopaedia of Islam. Second Edition, Leiden, Brill, 1978, vol. IV, p. 1027.

Garulo, Teresa, "Woman in Medieval Classical Arabic Poetry", en Manuela Marín y Randi Deguilhem (eds.), Writing the Feminine. Women in Arab Sources, Londres-Nueva York, I.B. Tauris, 2002, pp. 25-40.

González, Valerie, "Berbers", en Josef W. Meri (ed.), Medieval Islamic Civilization. An Encyclopedia, Nueva York-Londres, Routledge, 2006, I, pp. 105-106. Husayn, Fathịyya, Mu 'ğam ma 'ānì asmā' al-ināt, La Meca, 2000.

Jiménez Estacio, M. a del Mar, "Las mujeres bereberes de al-Andalus", II Congreso Virtual sobre Historia de las mujeres (15-31 Octubre 2010), 8 [en linea], disponible en: <http://www.revistacodice.es/publi_ virtuales/ii_congreso_mujeres/comunicaciones/ JIMENEZESTACIO.pdf>, [consultado el 06/07/2020].

Jud, Jakob y Steiger, Arnald (eds.), Vox romanica: Annales helvetici explorandis linguis romanicis destinati, Berna, Francke Verlag, 1960, vols. 13-14. 
Lane, Edward William, Arabic-English Lexicon, Londres, Willams \& Norgate, 1863.

Léandre Bargès, Jean Joseph, Complément de l'histoire des Beni-Zeiyan, rois de Tlemcen, París, Ernest Leroux, 1887.

Lévi-Provençal, E., Inscriptions arabes d'Espagne, Leyden-París, E. J. Brill - E. Larose, 1931.

Marcy, Georges, "Le vestiges de la parenté maternelle en droit coutumier berbère", Revue Africaine, 85 (1941), pp. 187-211.

Marín, Manuela, Individuo y sociedad en al-Andalus, Madrid, Mapfre, 1992.

Marín, Manuela, "Cercanas a Dios: la religiosidad de las mujeres en algunas sociedades islámicas pre-

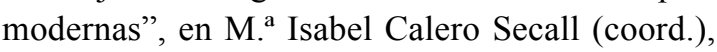
Mujeres y sociedad Islámica: una visión plural, Málaga: Universidad de Málaga, 2006, pp. 41-64.

Marín, Manuela, Mujeres en al-Andalus, Madrid, CSIC, 2000.

Martínez Enamorado, Virgilio, "Epigrafía meriní. Lectura y documentación de las inscripciones sobre cerámica estampillada del Museo de Algeciras", en Antonio Torremocha Silva y Yolanda Oliva Cózar (eds.), $L a$ cerámica musulmana de Algeciras. Producciones estampilladas. Estudios y catálogo, Algeciras, Fundación Municipal de Cultura «José Luis Cano», 2002, pp. 73-85.

Martínez Núñez, M. Antonia, “Las fuentes epigráficas. Siglos IX-X”, Jábega, 105 (2014), pp. 59-73.

Martínez Núñez, M. ${ }^{a}$ Antonia, "El proyecto almohade a través de la documentación epigráfica: innovación y ruptura", en P. Cressier y V. Salvatierra Cuenca (eds.), Miradas Cruzadas 1212-2012. La batalla de las Navas de Tolosa, Jaén, Universidad de Jaén, 2014, pp. 139-157.

Manzano Rodríguez, Miguel Ángel, La intervención de los Benimerines en la península Ibérica. Madrid, CSIC, 1992.

Manzano Rodríguez, Miguel Ángel, “Onomástica benimerín: el problema de la legitimidad”, en M. a Luisa Ávila (ed.), Estudios Onomástico-Biográficos de al-Andalus (EOBA, 2), Madrid, CSIC, 1989, pp. 119-136.

Manzano Rodríguez, Miguel Ángel, "Biografías y poder político: la imagen de los sultanes magrebíes en la Baja

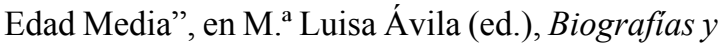
género biográfico en el occidente islámico, Madrid, CSIC, 1997, pp. 249-265.

Marmon, Shaun, Eunuchs \& Sacred Boundaries in Islamic Society, Nueva York-Oxford, Oxford University Press, 1995.

Meouak, Mohamed, Șaqāliba, eunuques et esclaves à la conquête du pouvoir. Géographie et histoire des élites politiques marginales dans l'Espagne umayyade, Helsinki, Academia Scientiarum Fennica, 2004.
Oussous, Mohamed, Lexique animal (Français-AmazigueArabe), California, Tawalt, s.d. [en linea], disponible en: $<$ http://www.tawalt.com/wp-content/books/tawalt_ books/amawal_imudren/animal_dictionary_1.pdf $>$. Qutbuddin, Tahera, "Fatima (al-Zahra) bint Muhammad (ca. 12 before Hijra-11 / ca. 610-632)", en Joseph W. Meri (ed.), Medieval Islamic Civilization. An Encyclopaedia, Nueva York-Londres, Routledge, 2006, vol. 1, pp. 248-250.

Rāgib, Yūsuf, "Esclaves et affranchis trahis par leur nom dans les arts de l'Islam medieval", en C. Müller y M- Roiland-Rouabah (dirs.), Le non-dits du nom. Onomastique et Documents en terres d'Islam, Beirut, Institut français du Proche-Orient, 2013, pp. 247-301.

Rodríguez Mediano, Fernando, Familias de Fez (ss. XV-XVII), Madrid, CSIC, 1995.

Ruska, J. y Plesner, M., "Anbar”, en H.A.R. Gibb, J.H. Kramers, E. Lévi-Provençal y J. Schacht (eds.), Encyclopaedia of Islam. Second Edition, Leiden, Brill, 1960, vol. I, p. 484.

Salahuddin, Ahmed, A Dictionary of Muslim Names, Nueva York, New York University Press, 1999.

Schimmel, Annemarie, Islamic names, Edimburgo, Edinburgh University Press, 1989.

Scott, Joan W., "El género: una categoría útil para el análisis histórico", en Marta Lamas (ed.), El género: la construcción cultural de la diferencia sexual, Méjico, Universidad Autónoma de Méjico, 1996, pp. 265-302.

Shatzmiller, Maya, L'historiographie mérinide: Ibn Khaldūn et ses contemporains, Leiden, E. J. Brill, 1982.

Shatzmiller, Maya, "Marīnids", en P. Bearman, Th. Bianquis, C.E. Bosworth, E. van Donzel y W.P. Heinrichs (eds.), Encyclopaedia of Islam, Second Edition, 2012, doi: http://dx.doi.org/10.1163/15733912 islam_SIM_4966.

Spellberg, Denise A., Politics, Gender, and the Islamic Past: The Legacy of 'A 'isha bint Abī Bakr, Nueva York, Columbia University Press, 1995.

Taïf, Miloud, Dictionnaire tamazight-français (parlers du Maroc central), Paris, L'Harmattan-Awal, 1991.

Tolmacheva, Marina A., "Concubines on the Road: Ibn Battuta's Slave Women”, en M.S. Gordon y K.A. Hein (eds.), Concubines and Courtesans: Women and Slavery in Islamic History. Oxford, Oxford University Press, 2017, pp. 163-189.

Vacca, Virginia y Roded, Ruth, “Ṣafiyya”, en H.A.R Gibb, J.H. Kramers, E. Lévi-Provençal y J. Schacht (eds.), Encyclopaedia of Islam, Second Edition, Leiden, Brill, vol. 8, 1995, doi: http://dx.doi.org/10.1163/15733912_islam_SIM_6451.

Veccia Vaglieri, Laura, "Fāṭima", en H.A.R Gibb, J.H. Kramers, E. Lévi-Provençal y J. Schacht (eds.), Encyclopaedia of Islam, Second Edition, Leiden, Brill, vol. 2, 1965, pp. 841-850. 
Viguera Molíns, M. ${ }^{a}$ Jesús, (ed.), La mujer en alAndalus. Reflejos históricos de su actividad y categorías sociales, Madrid-Sevilla, Universidad Autónoma de Madrid, Editoriales Andaluzas Unidas, 1989.

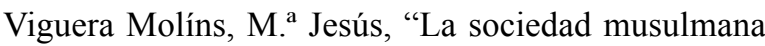
en al-Andalus: su reflejo en los textos", en Ricardo Izquierdo Benito y Ángel Sáenz-Badillos (eds.), $L a$ sociedad medieval a través de la literatura hispanojudía, Cuenca, Universidad de Castilla-La Mancha, 1998, pp. 29-52.

Watt, W. Montgomery, “' $\bar{A}$ ' isha bint Abī Bakr”, en H.A.R. Gibb, J.H. Kramers, E. Lévi-Provençal y J. Schacht (eds.), Encyclopaedia of Islam. Second Edition, Leiden, Brill, vol. I, 1960, pp. 307-308.
Watt, W. Montgomery, "KHadīdja”, en H.A.R. Gibb, J.H. Kramers, E. Lévi-Provençal y J. Schacht (eds.), Encyclopaedia of Islam. Second Edition, Leiden, Brill, vol. IV, 1978, p. 898.

Wensinck, A.J. y [Johnstone, Penelope], "Maryam”, en H.A.R. Gibb, J.H. Kramers, E. Lévi-Provençal y J. Schacht (eds.), Encyclopaedia of Islam. Second Edition, Leiden, Brill, vol. VI, 1978, p. 628.

\section{Webgrafía}

http://dictionnaire.sensagent.leparisien.fr/Beni\%20

Ourtilane/fr-fr/\#: : text=1\%2D\%20Beni $\% 20$

Ourtilane $\% 20$ est $\% 20$ dit,un $\% 20$ anc $\%$ C3\%AAtre $\% 20$ vaillant $\% 20$ et $\% 20$ invincible. 